\title{
Farklı Tip Betonarme Binalar İçin Geliştirilmiş Hasar Tahmin Yöntemleri
}

\author{
Ali GÜRBÜZ ${ }^{1}$ \\ Muhammed TEKİN ${ }^{2}$
}

ÖZ

$\mathrm{Bu}$ çalışmanın başlıca amacı; olası bir depremde meydana gelecek hasar ve kayıp olasılıklarını tahmin etmeye yarayan bir hasar tahmin metodu geliştirmektir. Bu amaçla; 11 farklı tip betonarme yapı için hasar olasılık grafikleri elde edilmiştir. Çalışma kapsamında 341 adet betonarme konut binas1; yapım yıll, kat adedi ve bina kalitesi gibi ortak özelliklerine göre gruplanmıştır. Toplam 11 farklı bina grubu elde edilmiştir. Binaların tamamı bilgisayar ortamında 3 boyutlu olarak modellenmiş ve her bir bina modeli nonlinear statik itme analizi ile analiz edilmiştir. Ardından, analizlerden elde edilen veriler kullanılarak her bina grubu için 4 farklı hasar olasılığını gösteren kırılganlık eğrileri çizilmiştir. 11 farklı bina grubu için toplam 44 kırılganlık eğrisi elde edilmiştir. Çalışma neticesinde elde edilen eğriler kullanılarak benzer özelliklere sahip binaların yer aldığı herhangi bir bölgedeki olası hasarları tahmin etmek mümkündür.

Anahtar Kelimeler: Deprem hasar tahminleri, kırılganlık eğrileri, hasar olasılıkları, betonarme binalar.

\section{ABSTRACT \\ Developing Damage Estimation Methods for Different Types of Reinforced Concrete Buildings}

The main purpose of this study is to develop a damage and loss estimation method for predicting earthquake damage in a possible earthquake. For this purpose; damage probability graphs have been drawn for 11 different types of reinforced concrete structures. In the study, 341 reinforced concrete buildings are grouped according to common features such as number of stories, age of the building, construction quality etc. A total of 11 different building groupings were obtained. All of the buildings are modeled by 3-D computer modeling and each was analyzed by nonlinear pushover analysis. Then, fragility curves for 4 different damage probabilities were plotted for each of the building groups using the data obtained from pushover analysis results. Total of 44 fragility curves were

\footnotetext{
Not: Bu yaz1

- Yayın Kurulu'na 03.11.2015 günü ulaşmıştır.

- 31 Aralık 2017 gününe kadar tartışmaya açıktır.

- DOI: 10.18400/tekderg.334196
}

1 Recep Tayyip Erdoğan Üniversitesi, İnşaat Mühendisliği Bölümü, Rize - ali.gurbuz@erdogan.edu.tr 2 Gelişim Üniversitesi, İnşaat Mühendisliği Bölümü, İstanbul - muhammed.tekin59@hotmail.com 
obtained for 11 different building groups. Using the fragility curves obtained by this study, it is possible to estimate the potential damage in any area of the buildings featuring similar characteristics.

Keywords: Earthquake loss estimation, fragility curves, damage probability, reinforced concrete buildings.

\section{GíRIŞ}

Ülkemiz topraklarının çok büyük bir bölümü hasar verici şiddette deprem tehlikesi altındadır [1]. Deprem etkileri altında betonarme binalarda oluşabilecek çeşitli hasarların önceden belirlenebilmesi her zaman önemli bir araștırma konusu olmuştur. Yaşanan depremler sonucu yapılarda oluşan büyük hasar ve ekonomik kayıplar, gelecek depremlerde oluşabilecek hasarın tahmin edilebilmesi için mevcut bina stokunun hasar görebilme riskinin değerlendirilmesi ihtiyacını ortaya çıkarmıştır [2]. Bu amaçla Türkiye'deki betonarme yapı stoku göz önüne alınarak yapılan çalışmalarda; deprem hasarları ve hasara neden olan parametreler araştırılmıştır $[3,4,5,6,7,8,9,10,11,12]$. Bu parametrelere bağlı olarak meydana gelebilecek olası hasarları tahmin edebilmek için geçmiş deprem verilerinden faydalanılmış ve çeşitli yöntemler geliştirilmiştir $[13,14,15,16]$. Kırılganlık eğrisi veya hasar olasıllı eğrisi olarak adlandırılan grafiklerden faydalanarak topyekûn hasarı tahmin etmek de son yıllarda üzerinde çalışılan metotlar arasındadır $[17,18,19,20]$. Kırılganlık eğrilerini elde etmek için deneysel ve analitik birçok yöntem kullanılabilmektedir $[2,11,13,14,17,19,21]$. Bu çalışmada; ülkemizdeki az ve orta katlı betonarme yapıların olası bir depremde karşılaşacağı hasarları tahmin etmek için artımsal itme analizi esaslı analitik yöntem tercih edilmiştir. Bu kapsamda; rasgele örneklem yöntemiyle seçilen ve farklı kat adedine sahip 341 adet betonarme konut binası için artımsal itme analizi esaslı yöntemle kırılganlık eğrileri elde edilmiştir. Çalışma kapsamında; mimari ve betonarme projeleri temin edilen binalar ortak özelliklerine göre 11 gruba ayrılmıştır. Doğrusal olmayan artımsal itme analizi ile 11 gruptaki her bir binanın yanal deplasman kapasitesini gösteren kapasite eğrileri elde edilmiştir. Bir sonraki adımda, çok serbestlik dereceli sistem için bulunan kapasite eğrilerine uygulanan koordinat dönüşümü ile modal kapasite diyagramları elde edilmiştir. Böylece, kırılganlık eğrilerine parametre olarak seçilen spektral deplasman değerleri de elde edilmiş olur. Kırılganlık eğrilerinin logaritmik dağılıma uyduğu varsayılarak, binalar için hesaplanan spektral deplasman değerlerinin doğal logaritmaları alınmıştır. Bir sonraki adımda; her bir grup için, gruptaki binalara ait spektral deplasman değerlerinin lognormal ortalaması ve lognormal standart sapması hesaplanmıştır. Son olarak; tahmin edilecek olası hasarı derecelendirmek için 4 farklı hasar olasılık sınırı belirlenmiştir. Hesaplanan sınır değerleri yardımıyla, her bir hasar seviyesi için hasar olasılıklarını gösteren kırılganlık eğrileri çizilmiştir.

\section{2. ÇALIŞMADAKI BINNALARA AİT ISTTATISTIKLER VERILER}

Çalışmada incelenen binalar hakkındaki veriler mevcut binaların betonarme ve mimari projelerinden elde edilmiştir. Sismik risk analizinde kullanılacak olan verilerin düzenlenmesi amacıyla, binalar ortak karakteristik özellikleri dikkate alınarak sınıflandırılmıştır. 


\subsection{Kat Adedi}

Çalışmada analiz edilen binaların \%6'sı tek katlı, \%17'si iki katlı, \%12'si üç katll, \%9'u dört katlı, \%23'ü beş katlı, \%18'i altı katlı ve \%15'i yedi katlı betonarme konuttan oluşmaktadır.

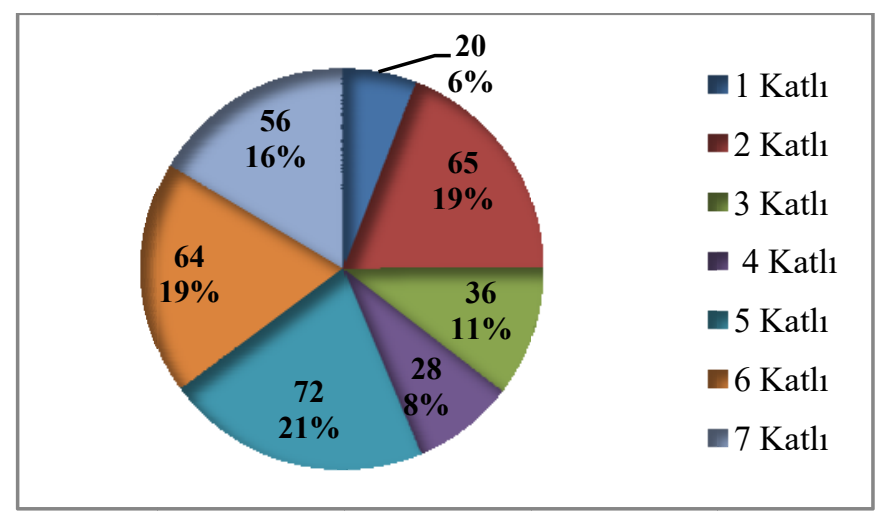

Şekil 1. Binaların kat adedine göre dağılımı

Şekil 1'deki daire grafik; bu çalışmada kullanılan toplam 341 adet binanın kat adedine göre dağılımını göstermektedir.

\subsection{Yapım Yılı}

$\mathrm{Bu}$ çalışmada kullanılan betonarme konut binaları 1975-2012 yılları arasında inşa edilmiştir. Şekil 2'deki daire grafik; çalışmada kullanılan binaların yapım yılına göre dağılımını göstermektedir.

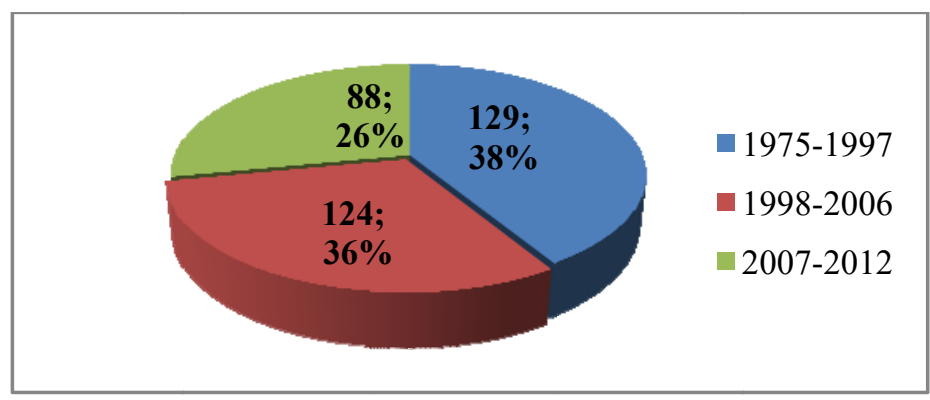

Şekil 2. Yapım yılına göre bina saylları

Calıșma envanterindeki binaların \%38'i 1975 ile 1997 yılları arasında, \%36's1 1998 ile 2006 yılları arasında, \%26's1 2007 sonrasında inşa edilmiştir. Grafikte görüldüğü gibi; analiz edilen binaların \%38'ini 1998 öncesi binalar oluşturmaktadır. 


\subsection{Taşıyıcı Sistem Türü}

Binaların taşıyıcı sistemi belirlenerek, betonarme çerçeve (BAÇ) veya betonarme çerçeve ve perde (BAÇP) sistemlerinden biri olarak seçilmiştir. Bu çalışmada BAÇP sistemli binalar ayrı bir grup içinde ele alınmıştır. . İncelenen $1-4$ katlı yapılarda perde duvara rastlanmazken, 5 katlı 1 yapıda, 6 katlı yedi binada ve 7 katlı on binada perde duvar bulunmaktadır. Şekil 3 çalışmada ele alınan 341 adet binanın taşıyıcı sistem türüne göre dağılımını göstermektedir.

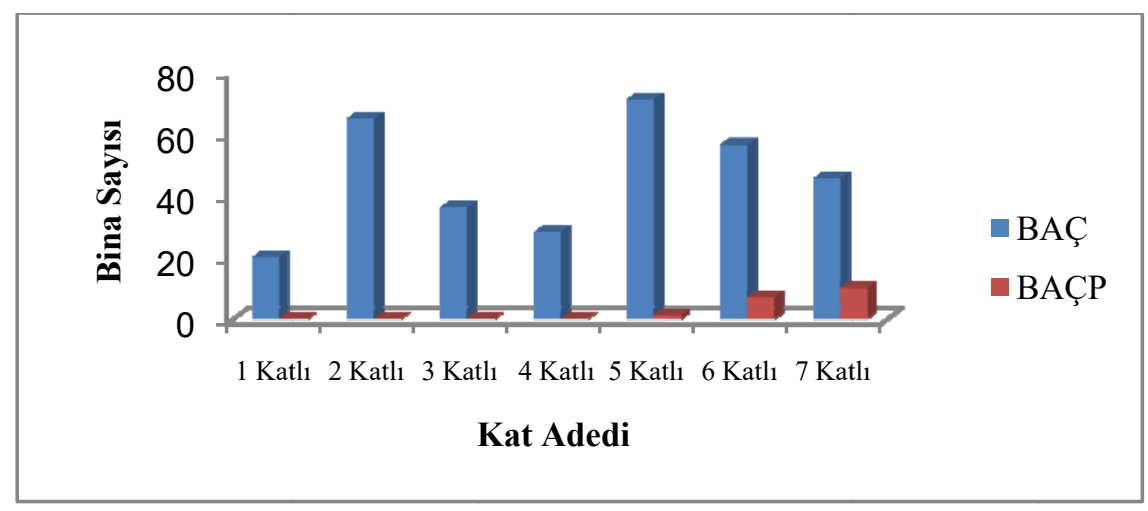

Şekil 3. Taşıylcı Sistem Türünün Kat Adedine Göre Dă̆ıllımı

Grafiğe göre toplam 18 adet binanın taşıyıcı sistem yapısı BAÇP ve 323 adet binanın taşıyıcı sistemi BAÇ'dir

\subsection{Yumuşak Kat/Zayıf Kat}

Mevcut envanterdeki 54 binada yumuşak ve/veya zayıf kat bulunmaktadır. Tek katlı yapılarda teknik olarak bu düzensizlik bulunamayacağından, envanterdeki 2-7 katlı binaların durumu ele alınmıştır. Envanterde bulunan iki katlı yapılarda da yumuşak kata rastlanmamıştır. Diğer kat adedindeki binaların dağılımı ise Şekil 4 'te grafiksel olarak görülmektedir.

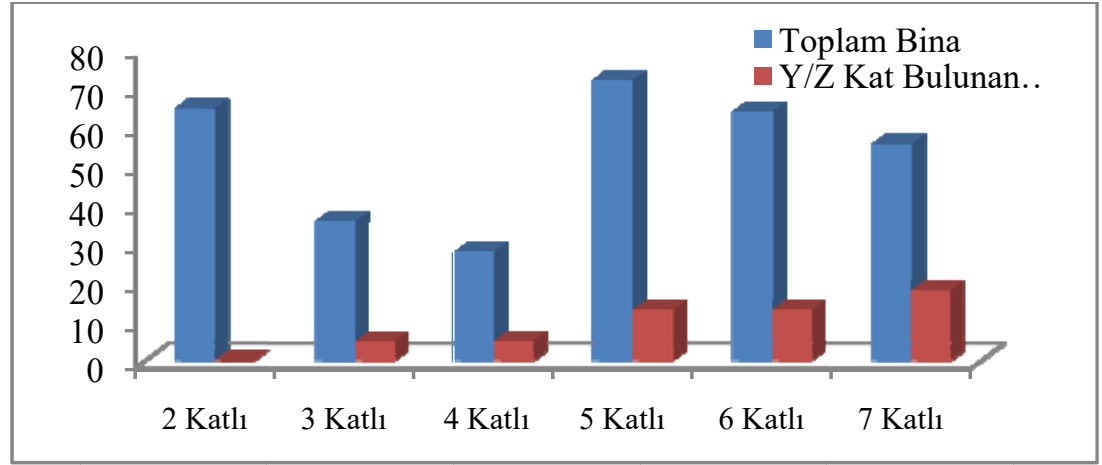

Şekil 4. Yumuşak/Zaylf Kat bulunan binaların katlara göre dağılımı 
Grafikte görüldüğü gibi; üç ve dört katlı binalardan 5'er tanesinde, beş ve altı katlı binaların 13 'er tanesinde ve yedi katlı binaların 18 tanesinde zayıf/yumuşak kat bulunmaktadır.

\subsection{Ağır çıkmalar}

İncelenen yapılarda en sık rastlanan olumsuzluk ağır çıkmalar olmuştur. Envanterdeki ağır çıkma bulunan binaların kat adedine göre dağılımı Şekil 5 'teki gibidir.

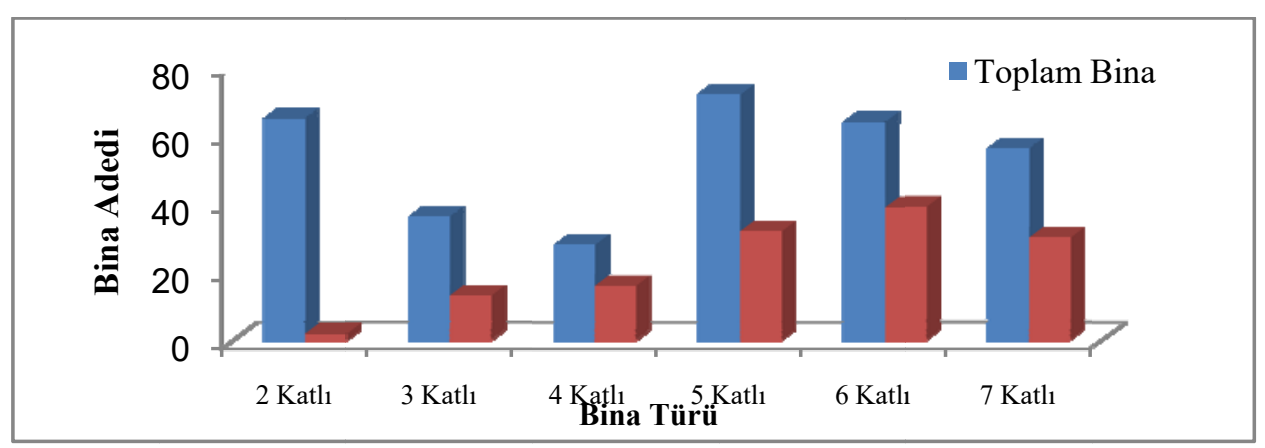

Şekil 5. Ağır çıkma bulunan binaların kat adedine göre dă̆ılımı

Çalışmada incelenen binaların 132 tanesinde ağır çıkmaya rastlanmıştır. Şekil 5'teki sütun grafikte; binadaki kat adedi arttıkça ağır çıkma kullanımına daha fazla rastlandığı görülmektedir. 4 kat ve üzeri binalar dikkate alındığında her iki binadan birinde ağır çıkmaya rastlanmaktadır. Veriler; kat planında çıkma yapmanın deprem açısından olumsuz bir parametre olmasına karşın, kullanılabilir bina alanına önemli ölçüde katkı sağlaması nedeniyle yaygın olarak kullanıldığını göstermektedir.

\subsection{Planda Düzensizlik/Burulma Etkisi}

İncelenen 341 adet betonarme konutun 58'inde planda düzensizlikler bulunmaktadır. Planda düzensiz binaların dağılımı Şekil 6'daki sütun grafikte görülmektedir. Grafikte görüldüğü gibi incelenen binalarda $\% 15$ oranında planda düzensizlik bulunmaktadır.

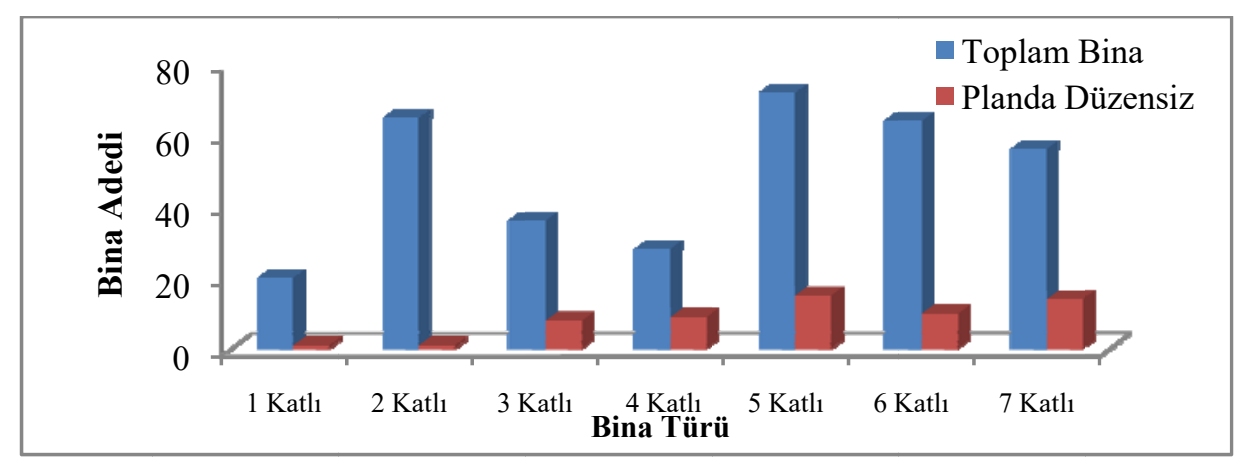

Şekil 6. Planda düzensizliğe sahip binaların kat adedine göre dă̆ılımı 


\section{YAPI TIPPLERINIIN BELİRLENMESI}

İncelemeye tabi tutulan binaların taşıyıcı sistemleri ile ilgili öne çıkan bazı ortak özellikler aşağıdaki gibidir:

- Kat sayısı 6'dan az olan binalarda perde-çerçeve sistemin kullanımına rastlanmamıştır.

- Binaların tasarımında dikkate alınan hareketli yük değerleri iç mekânlarda 2 $\mathrm{kN} / \mathrm{m} 2$, merdiven ve balkonlarda ise $3,5 \mathrm{kN} / \mathrm{m} 2$ ve $5 \mathrm{kN} / \mathrm{m} 2$ 'dir.

- Projesi incelenen yapıların kat yüksekliğine bakıldığında; genellikle 2,65 m, 2,70 $\mathrm{m}$ ve 2,80 m değerleri ön plana çıkmaktadır. Zemin katı ticari amaçla kullanılan binalarda ise kat yüksekliğinin 4 m'ye kadar çıktığı görülmektedir.

- Projesi incelenen betonarme konutlarda en yaygın kullanılan kiriş kesiti $25 / 50 \mathrm{~cm}$, kolon boyutları çoğunlukla $25 / 40 \mathrm{~cm}$ 'den başlamak üzere kat sayısı ve projesine göre değişkenlik göstermektedir.

- İncelenen binaların kesit ve malzeme gibi bazı özellikleri birbirlerine yakın olmakla birlikte; kat adedi, planda ve düşeyde düzensizlik durumları gibi sismik analizleri olumsuz etkilediği bilinen birçok değişkene daha sahiptirler.

İncelenen binalardan elde edilen verilere göre mevcut yapı tiplerinin sınıflandırılması üç farklı kıstas göz önüne alınarak yapılmıştır. Bunlar sırasıyla; bina proje yılı, kat adedi ve bina kalitesidir. Çalışmada kullanılan betonarme konut binaları, yapım yıllarına göre; 1998 öncesi yapılar ve 1998 ile sonraki yıllarda inşa edilen yapılar olmak üzere 2 grupta ele alınmıştır.

$\mathrm{Bu}$ çalışmanın temelinde binaların yanal deplasman kapasitelerine dayalı analizler yer aldığından, binaların kat adetlerine göre sınıflandırılması da kaçınılmaz olmuştur. Buna göre; ele alınan binalar, "1 ile 2 katlı yapılar", "3-5 katlı yapılar" ve "6-7 katlı yapılar" olmak üzere üç gruba ayrılmıştır.

Kalite puanlamasında ise; mevcut binaların hızlı bir şekilde değerlendirilebilmesi için "Riskli Bina Tesbit Esasları" hakkındaki yönetmelikte önerilen birinci kısım değerlendirme yöntemi uygulanmıştır [22]. Kalite puanlamasına göre sıralanan binalarda; 65 puanın aşağısı kötü kalite, 65 puan ve üzeri iyi kalite olarak kabul edilmiştir. Yönetmeliğin önerdiği birinci aşama hızlı değerlendirme yönteminde yer alan en büyük olumsuzluk parametreleri, ağır çıkma ve yumuşak kat olarak göze çarpmaktadır. Tek katlı konutlarda ağır çıkma, düşey düzensizlik ve yumuşak kat hiç bulunmazken, 2 katlı konutların tamamına yakınında da bu olumsuzluk parametreleri bulunmadığından performans puanları yüksek çıkmıştır. Bu nedenle 1 ve 2 katlı yapılarda 2 Temmuz yönetmeliğinde önerilen birinci aşama değerlendirme yöntemine göre kötü kalite bina grubu oluşturulamamıştır. 1 ve 2 katlı binalar sadece yapım yılına göre 1998 öncesi ve sonrası olarak iki gruba ayrılabilmiştir. Çalışmada değerlendirilen 1 ve 2 katlı binaların tamamında olumsuzluk puanları 70 puanın üzerinde ve puanlar kısmen birbirine yakın olduğundan 1 ve 2 katlı yapılarda kalite sınıflandırması yapılamamıştır. 1 ve 2 katlı yapılar sadece 1998 öncesi (98Ö12) ve 1998 sonrası (98S12) olmak üzere 2 gruba ayrılmıştır. Binalarla yapılan bütün değerlendirmelerin neticesinde 11 adet betonarme yapı tipi elde edilmiştir. Toplam 11 adet yapıt tipinin kodları ve isimleri aşağıdaki gibidir: 
$980 ̈ 12=1998$ öncesi inşa edilmiş 1-2 katlı betonarme çerçeveler

98S12 = 1998 ve sonrası inşa edilmiş 1-2 katlı betonarme çerçeveler

98Ö35I = 1998 öncesi inşa edilmiş 3-5 katlı iyi kalite betonarme çerçeveler

98S35 $\dot{I}=1998$ ve sonrası inşa edilmiş 3-5 katlı iyi kalite betonarme çerçeveler

98Ö35K = 1998 öncesi inşa edilmiş 3-5 katlı kötü kalite betonarme çerçeveler

98S35K = 1998 ve sonrası inşa edilmiş 3-5 katlı kötü kalite betonarme çerçeveler

98Ö67İ = 1998 öncesi inşa edilmiş 6-7 katlı iyi kalite betonarme çerçeveler

98S67I $=1998$ ve sonrası inşa edilmiş 6-7 katlı iyi kalite betonarme çerçeveler

98Ö67K = 1998 öncesi inşa edilmiş 6-7 katlı kötü kalite betonarme çerçeveler

$98 \mathrm{~S} 67 \mathrm{~K}=1998$ ve sonrası inşa edilmiş 6-7 katlı kötü kalite betonarme çerçeveler

P67 = 6-7 katlı betonerme perde+çerçeve sistemler

\section{BINALARIN ARTIMSAL ITTME ANALIZZLERİ}

Çalışma kapsamında sınıflandııllan binalar, CSI SAP2000 programı ile modellenerek statik itme eğrileri, yanal kat ötelênmeleri ve gerekli modal parametreler ( Tn, $\Gamma \mathrm{n}, \Phi \mathrm{Nn}, \mathrm{Mn}$ ) elde edilmiştir. Bu parametrelerden Tn: n. moda ait periyot, $\Gamma$ n: n. moda ait katılım çarpanı, $\Phi$ Nn: n. moda ait N. Kat (en üst kat) modal genliği, M: n. moda ait etkin kütleyi temsil etmektedir. Yapı elemanları modellenirken kolonlar; moment ve eksenel yük taşıyan betonarme çubuk eleman olarak modellenmiştir. Kirişlerin sadece eğilme momentine maruz kaldığ 1 varsayılmıştır. Beton ve çeliğin malzeme modeli için "Mander Modeli" kullanılmıştır [23]. Kesitlerin kesme kapasiteleri denklem 1 ile hesaplanmıştır. Analizlerde yapı-zemin etkileşimi dikkate alınmamıştır.

$V_{S}=\frac{\pi}{2} \frac{A_{s} f_{y h} D^{\prime}}{s}$

Denklemde; $\mathrm{V}_{\mathrm{s}}$, kesme kapasitesine çeliğin katkısı, $\mathrm{A}_{\mathrm{s}}$, çelik kesit alanı, D' donatı çapı, $\mathrm{f}_{\mathrm{yk}}$, çeliğin akma dayanımı ve s, donatı çubukları arasındaki boşluğu temsil etmektedir. Kesme kapasitesine betonun katkısı ise denklem 2 ile hesaplanmıştır.

$V_{c}=2\left[1+\frac{P_{e}}{2000 A_{g}}\right] \sqrt{f_{c}^{\prime}} A_{e}$

Denklem 1 ve 2'de; $V_{c}$, kesme kapasitesine betonun katkısı, $P_{e}$, kesite etkiyen yük, $\mathrm{f}_{c}$, beton dayanımı, $A_{g}$, beton kesit alanı ve $A_{e}$, etkili beton kesit alanıdır. Binaların dinamik özellikleri, kütlelerle uyumlu olarak yapı modellerine etki ettirilen düşey yüklere göre doğrusal olmayan statik analiz ile hesaplanmıştır. Bu analizin sonuçları aynı zamanda artımsal itme analizinin başlangıç koşulu olarak dikkate alınmıştır. Analizde doğrusal elastik olmayan davranışın idealleştirilebilmesi için yığılı plastik davranış modeli esas alınmıştır. Bu yaklaşımla çubuk eleman olarak idealleştirilen kiriş, kolon ve perde türü 
taşıyıcı sistem elemanlarındaki iç kuvvetlerin plastik kapasitelerine eriştiği sonlu uzunluktaki bölgeler boyunca, plastik şekil değiştirmelerin düzgün yaylı biçimde oluştuğu varsayılmıştır [2, 21]. Plastik mafsal boyu olarak adlandırılan bu bölgede; en büyük plastik şekil değiştirme değeri, mafsal boyunca sabit kabul edilmiştir.

Her bir bina iki farklı doğrultuda analiz edilmiş, böylece toplam 682 kapasite eğrisi elde edilmiştir. Her bina için zayıf yöndeki kapasite eğrisi dikkate alınmıştır. Kırılganlık eğrisi parametresi olarak spektral deplasman tercih edildiği için, elde edilen kapasite eğrileri Deprem Yönetmeliği 2007'de önerilen dönüşümle modal kapasite diyagramına dönüştürülmüştür [24]. Bu çalışmadaki 11 bina grubunun her birinden o grubu en iyi temsil edeceği düşünülen birer adet medyan bina seçilmiştir. Seçilen binaların modal kapasite eğrileri Şekil 7'de görülmektedir.

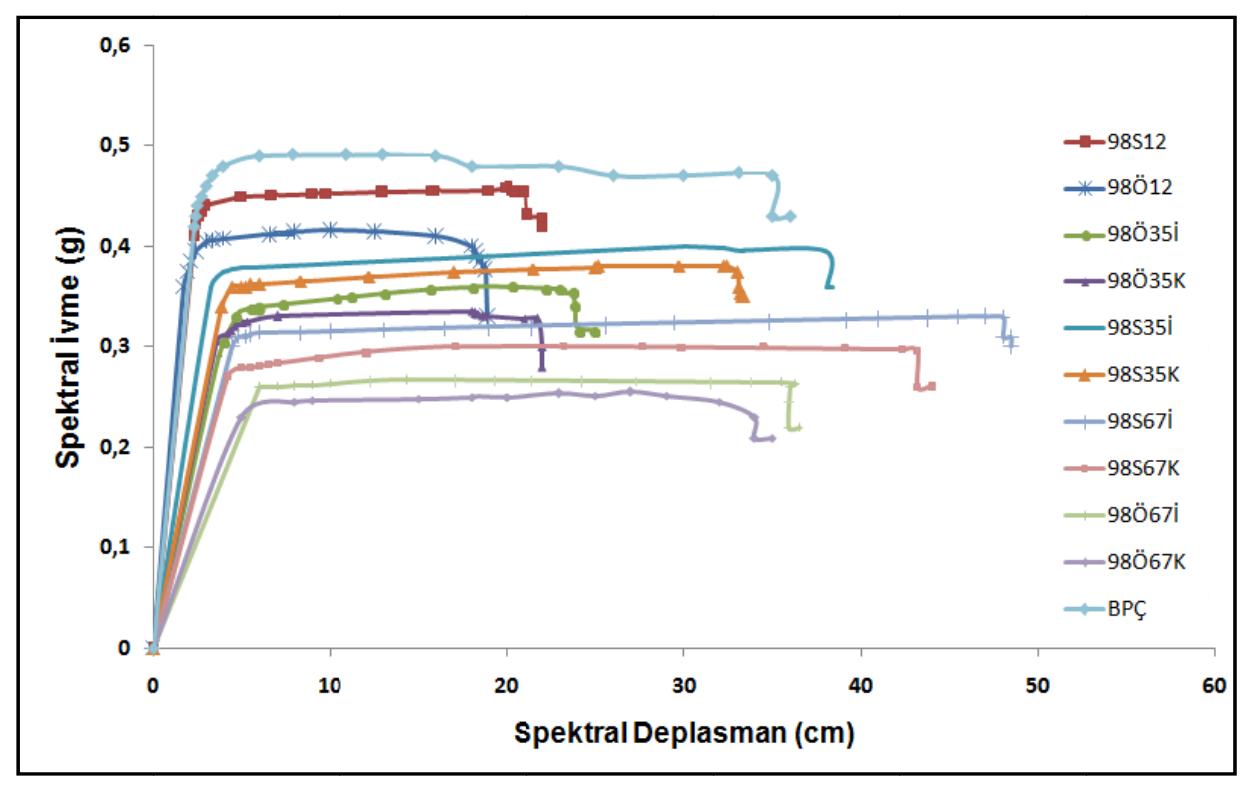

Şekil 7. Medyan Modal Kapasite Ĕgrileri

\section{HASAR SINIRLARI}

Yukarıda açıklandığı üzere bir kırılganlık eğrisi; belirlenen hasar sınırına ulaşılması veya bu sınırın aşılması olasılığını gösteren eğridir. Bu nedenle; hasar olasılık sınırları, kırılganlık eğrilerinin hesaplanmasında temel kıstaslardan birisidir. Konuyla ilgili yapılan ulusal ve uluslararası çalı̧̧malarda; betonarme binalar için birçok hasar seviyesi tanımlanmış ve kullanılmıştır. Binadaki hasarı 3, 4, 5 veya daha çok farklı seviyede tanımlamak mümkündür. Yapısal elemanların hasar durumları, bina kapasite eğrisinin eğimi veya yapının katlar arası ötelenme oranı gibi pek çok kıstas üzerinden hasar sınırları tespit edilebilmektedir. Bu çalışmada İstanbul ve İzmir Deprem Master Planlarında da benimsenen hasar seviyeleri kullanılmıştır. Bunlar; FEMA Hazus Mh Mr5 programında önerilen katlar arası ötelenme oranına bağlı 4 hasar seviyesidir [25]. Tablo 1 çalışmada sınıflandırılan her bir grup için ötelenme oranına bağlı hasar durumlarını göstermektedir. 
Tablo 1. Ötelenme Oranına Bağll Hasar Durumlart

\begin{tabular}{|c|c|c|c|c|}
\hline Grup & Hafif Hasar & Orta Hasar & Ăğır Hasar & Çok Ăğır Hasar \\
\hline 98012 & 0,005 & 0,008 & 0,02 & 0,05 \\
\hline $98 \mathrm{~S} 12$ & 0,005 & 0,0087 & 0,0233 & 0,06 \\
\hline $\begin{array}{l}98 \mathrm{O} 35 \mathrm{I} \\
98 \mathrm{O} 35 \mathrm{~K} \\
98 \mathrm{O} 67 \mathrm{I} \\
98 \mathrm{O} 67 \mathrm{~K}\end{array}$ & 0,0033 & 0,0053 & 0,0133 & 0,0333 \\
\hline $\begin{array}{l}98 \mathrm{~S} 35 \mathrm{I} \\
98 \mathrm{~S} 35 \mathrm{~K} \\
98 \mathrm{~S} 67 \mathrm{I} \\
98 \mathrm{~S} 67 \mathrm{~K}\end{array}$ & 0,0033 & 0,0058 & 0,0156 & 0,04 \\
\hline Perdeli & 0,002 & 0,004 & 0,01 & 0,02 \\
\hline
\end{tabular}

\section{KIRILGANLIK EĞRILERININ ÇIZILMESI}

Kırılganlık eğrileri özetle; sınır hasar seviyeleri belirlenen binaların birikimli dağılımını gösteren, birikimli dağılım fonksiyonlarıdır. Uygulamada bir kırılganlık eğrisinin çizimi, bu eğriyi niteleyen $\overline{S_{d_{s_{i}}}}$ ve $\beta_{d_{s_{i}}}$ parametrelerinin belirlenerek denklem 3'te yerine konulmasından ibarettir.

$P d \geq\left(d_{S_{i}} \mid S_{d}\right)=\varphi\left(\frac{\ln \left(S_{d}\right)-\overline{S_{d_{S_{i}}}}}{\beta_{d_{S_{i}}}}\right)$

Denklem 3'te; P sembolik olarak hasar olasılığını. $\overline{S_{d_{s_{i}}}}$ bina hasarının ilgili hasar seviyesine eriştiği ortalama modal yerdeğiştirmeyi, $\beta_{d_{s_{i}}}$, ilgili sınır hasar seviyeleri için modal yerdeğiştirme değerlerinin doğal logaritmalarına ait standart sapmayı, $\varphi$ ise birikimli standart dağılım fonksiyonunu göstermektedir.

Çalışma kapsamında sınıflandırılan her bir bina için, sınır spektral yerdeğiştirme değerlerinin doğal logaritmaları alınmıştır. Çalışmada 11 ayrı grup ve 4 farklı hasar seviyesi için toplam 44 hasar olasılık eğrisi tanımlanmıştır. Her bir eğri için, ilgili binaların sınır değerleri kullanılarak logaritmik ortalama ve logaritmik standart sapmaları hesaplanmıştır. Hesaplanan $\beta_{d_{s_{i}}}$ ve $\overline{S_{d_{s_{i}}}}$ parametreleri denklem 3'te yerine konarak, kırılganlık eğrileri elde edilmiştir.

Bu çalışmadaki 11 grup binanın ortalama $\overline{S_{d_{s_{i}}}}$ ve $\beta_{d_{s_{i}}}$ parametreleri tablo 2'de görüldüğü gibidir.

Tablo 2'de; 11 grup ve 4 farklı hasar seviyesi için toplam 44'er adet lognormal ortalama ve lognormal standart sapma hesaplanmıştır. Bu parametrelerin denklem 3 'te yerine konması sonucu elde edilen kırılganlık eğrileri ise Şekil 8'de verilmiştir. 
Farklı Tip Betonarme Binalar İçin Geliştirilmiş Hasar Tahmin Yöntemleri

Tablo 2; Hasar sinırlarına göre olasllı yoğunluk fonksiyonu parametreleri

\begin{tabular}{|l|l|l|l|l|l|l|l|l|}
\hline \multirow{2}{*}{ GRUP } & \multicolumn{7}{|c|}{ Olas1lk Yoğunluk Fonksiyonu Parametreleri (cm) } \\
\cline { 2 - 9 } & \multicolumn{2}{|c|}{ Sd1 (Hafif Hasar) } & \multicolumn{2}{|c|}{ Sd2 (Orta Hasar) } & \multicolumn{2}{c|}{ Sd3 (Ağır Hasar) } & \multicolumn{2}{|c|}{$\begin{array}{c}\text { Sd4 (Çok Ağır } \\
\text { Hasar) }\end{array}$} \\
\cline { 2 - 9 } & Log.Ort & L.Std.Sp & Log.Ort & L.Std.Sp & Log.Ort & L.Std.Sp & Log.Ort & L.Std.Sp \\
\hline 98Ö12 & 0,8373 & 0,3714 & 1,3016 & 0,3947 & 2,3134 & 0,4693 & 2,6892 & 0,4013 \\
\hline 98S12 & 1,0919 & 0,3236 & 1,6621 & 0,3978 & 2,6015 & 0,3950 & 2,9481 & 0,3952 \\
\hline 98Ö35K & 1,0168 & 0,3327 & 1,2622 & 0,3598 & 2,2250 & 0,3404 & 2,2822 & 0,4105 \\
\hline 98Ö35I & 1,3867 & 0,3287 & 1,9121 & 0,3869 & 2,7425 & 0,3841 & 3,0141 & 0,3813 \\
\hline 98S35I & 1,2646 & 0,5216 & 1,9667 & 0,45308 & 2,8431 & 0,33548 & 3,3175 & 0,2958 \\
\hline 98S35K & 1,1119 & 0,3714 & 1,6086 & 0,4047 & 2,4990 & 0,4708 & 2,8339 & 0,3994 \\
\hline 98Ö67I & 1,482 & 0,4503 & 2,3163 & 0,4209 & 3,0164 & 0,2908 & 3,4478 & 0,3273 \\
\hline 98Ö67K & 1,282 & 0,413 & 1,9956 & 0,3308 & 2,8507 & 0,3311 & 3,2837 & 0,2921 \\
\hline 98S67I & 1,527 & 0,3431 & 2,1303 & 0,4501 & 2,1395 & 0,3760 & 3,5314 & 0,3412 \\
\hline 98S67K & 1,3305 & 0,4271 & 1,9793 & 0,4136 & 2,8806 & 0,3542 & 3,1710 & 0,2785 \\
\hline Perdeli & 0,1384 & 0,2806 & 0,7175 & 0,3977 & 1,5463 & 0,4012 & 2,0323 & 0,4222 \\
\hline
\end{tabular}

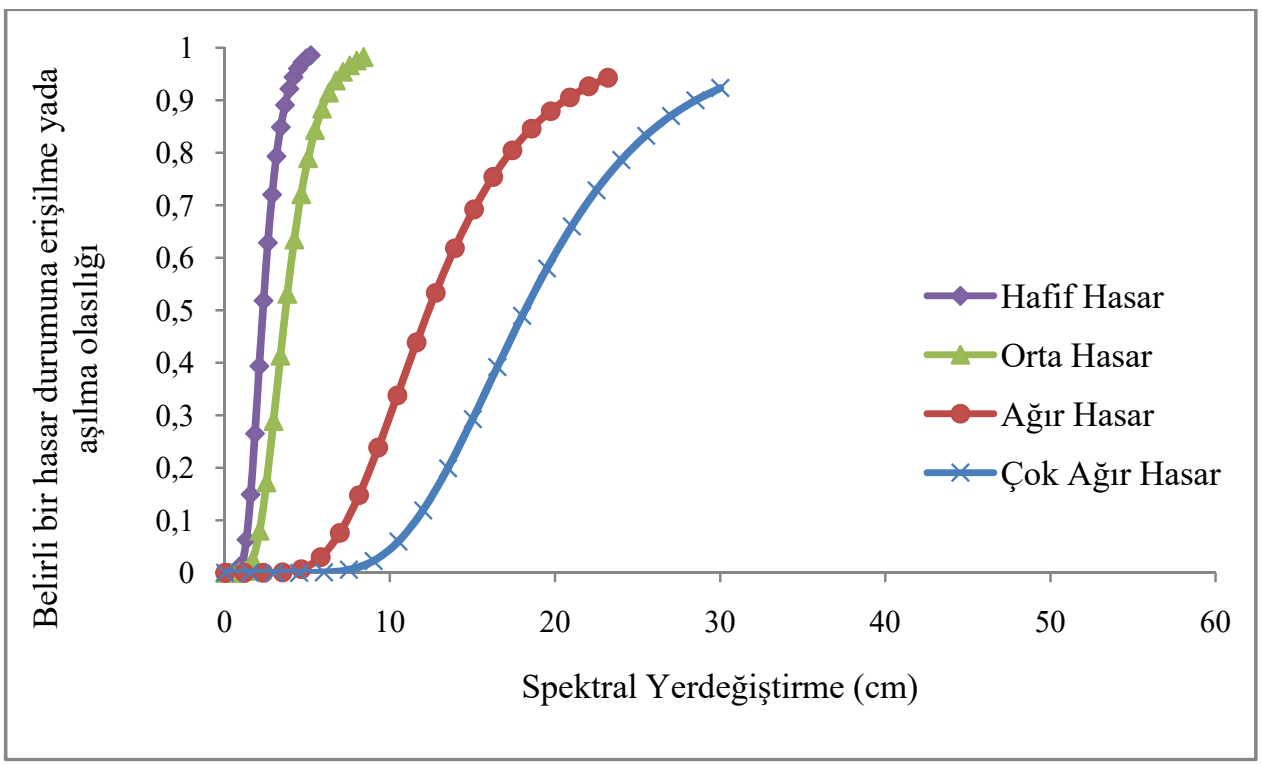

Şekil 8. Grup 98012 kirllganlı eğrileri 


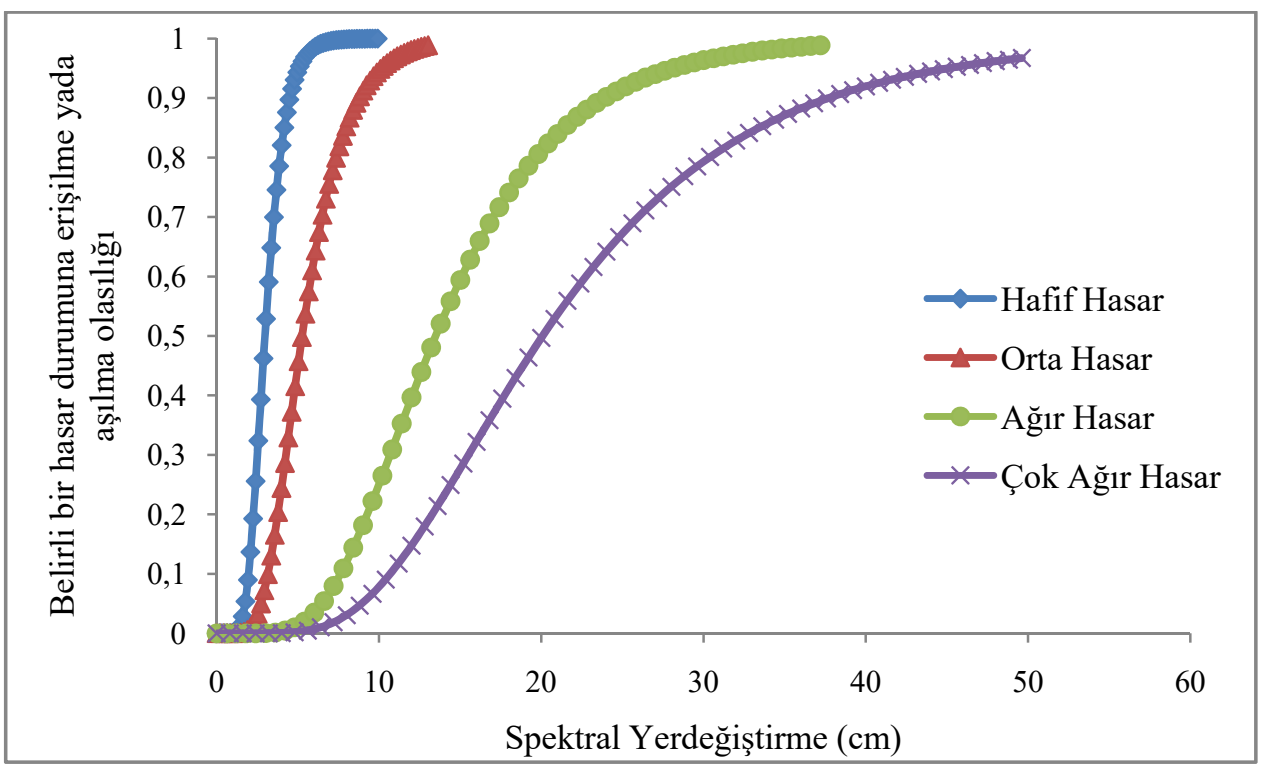

Şekil 9. Grup 98 S12 kurllganlı e ğrileri

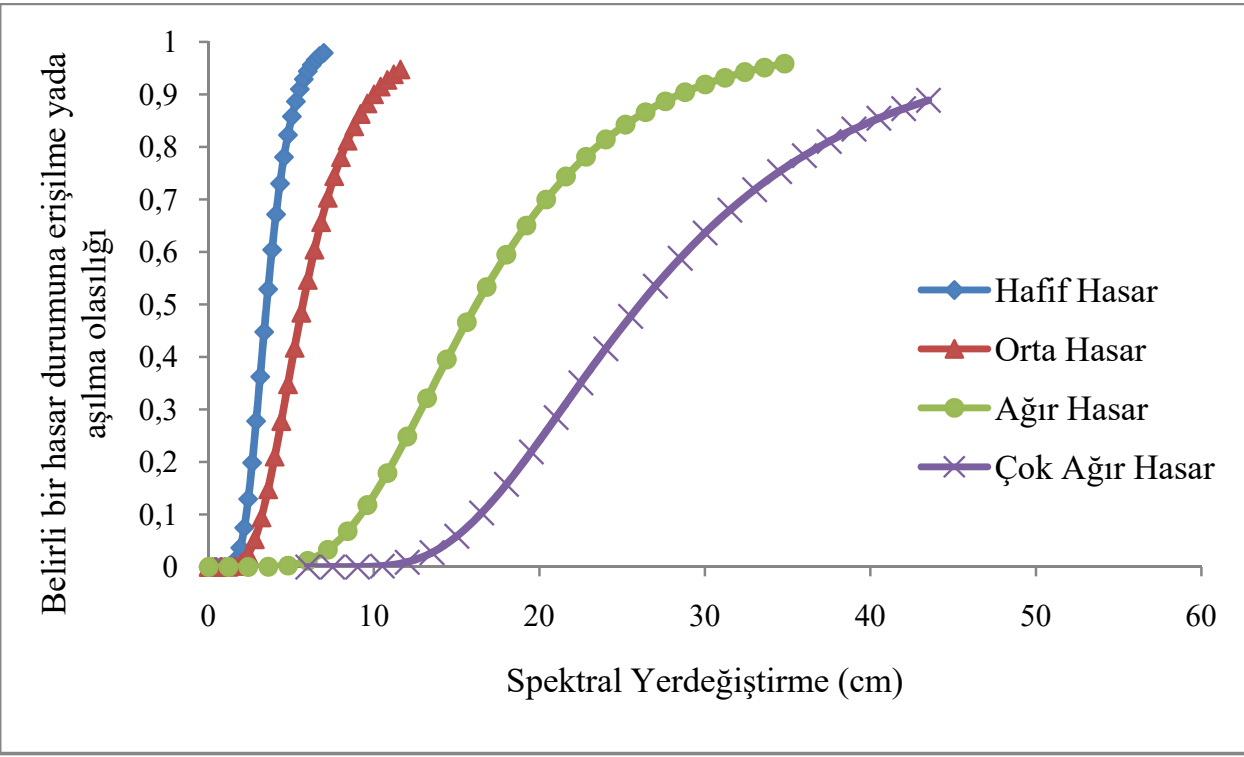

Şekil 10. Grup 98Ö35İ kirllganlık eğrileri 
Farklı Tip Betonarme Binalar İçin Geliştirilmiş Hasar Tahmin Yöntemleri

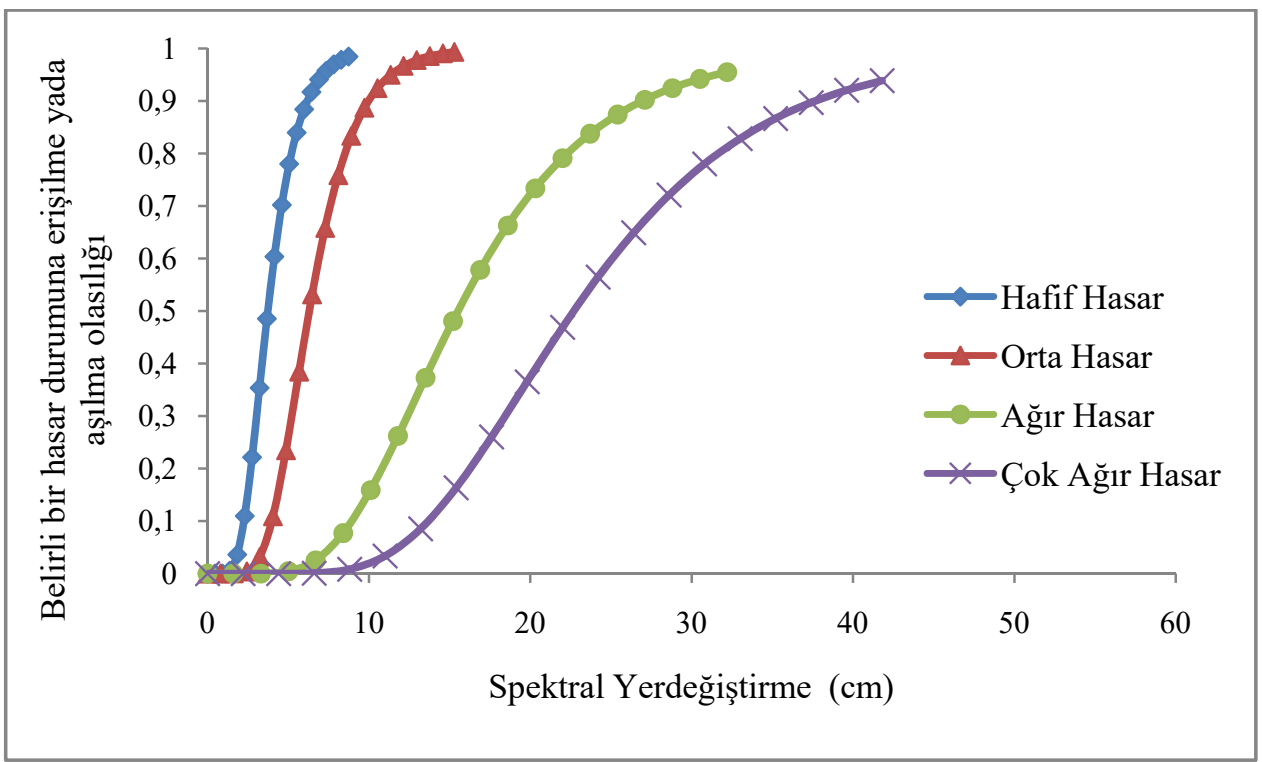

Şekil 11. Grup 98Ö35K kirllganlı ĕ̆rileri

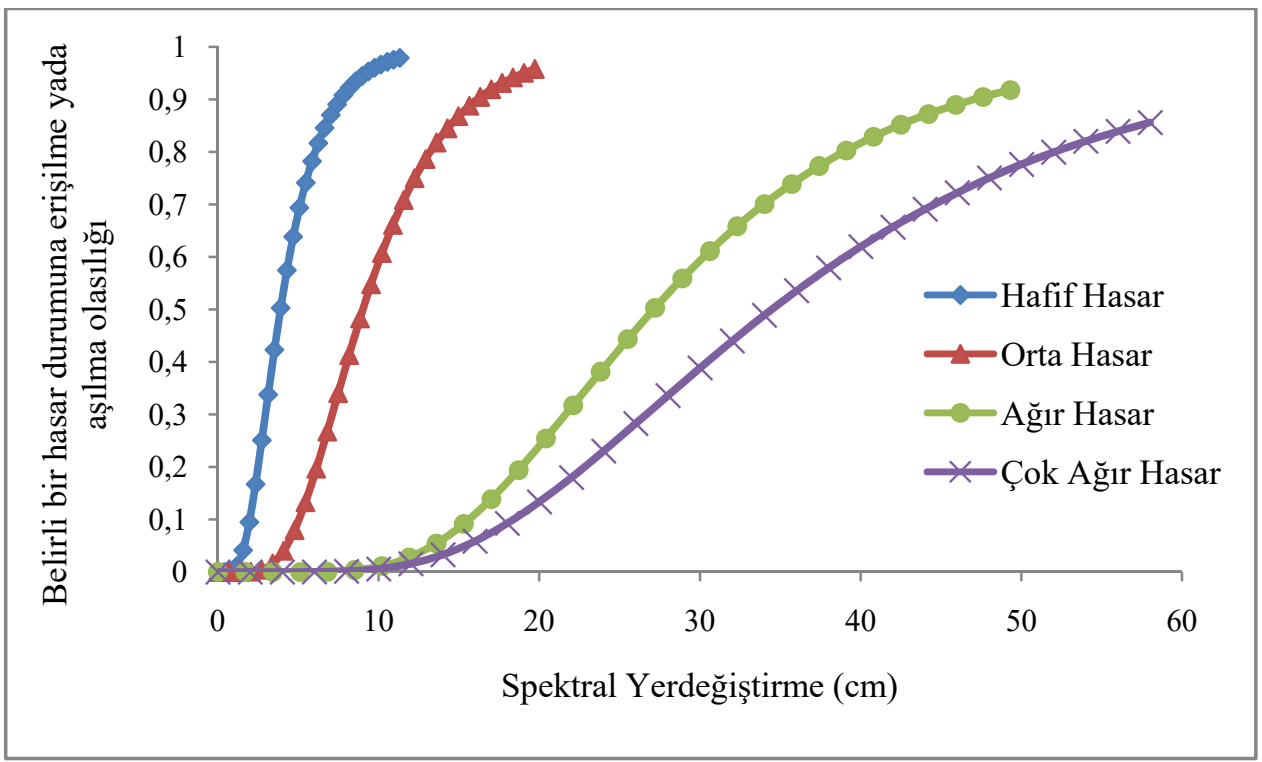

Şekil 12. Grup 98S35í kirllganlı eğrileri 


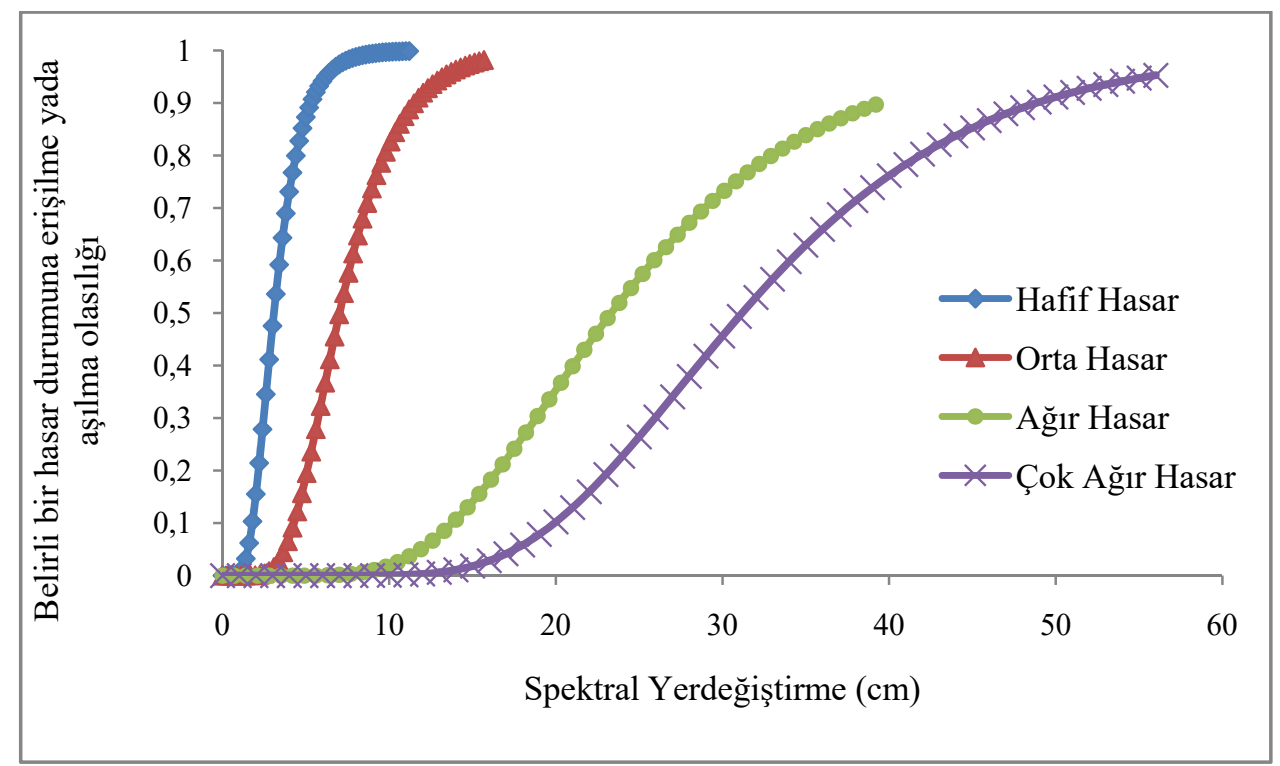

Şekil 13. Grup 98S35K kirllganlık ĕgrileri

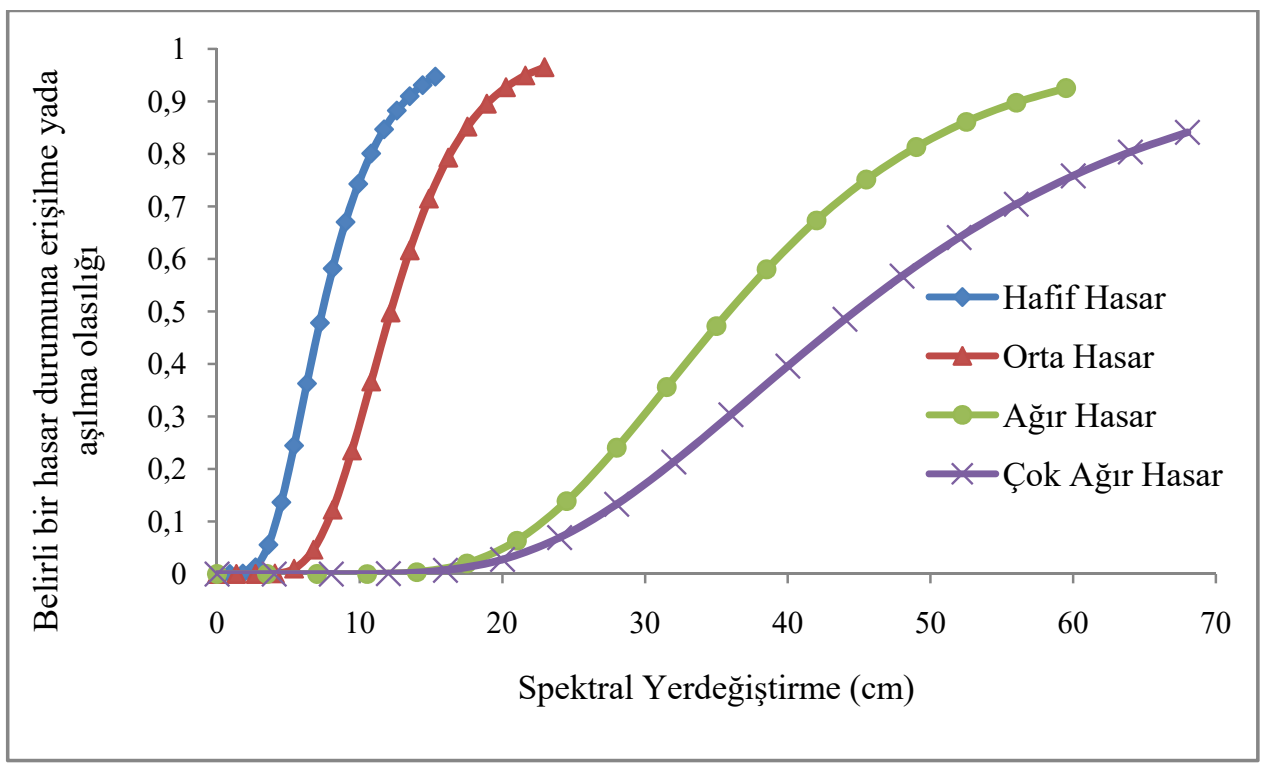

Şekil 14. Grup 98Ö67i kirllganlık eğrileri 
Farklı Tip Betonarme Binalar İçin Geliştirilmiş Hasar Tahmin Yöntemleri

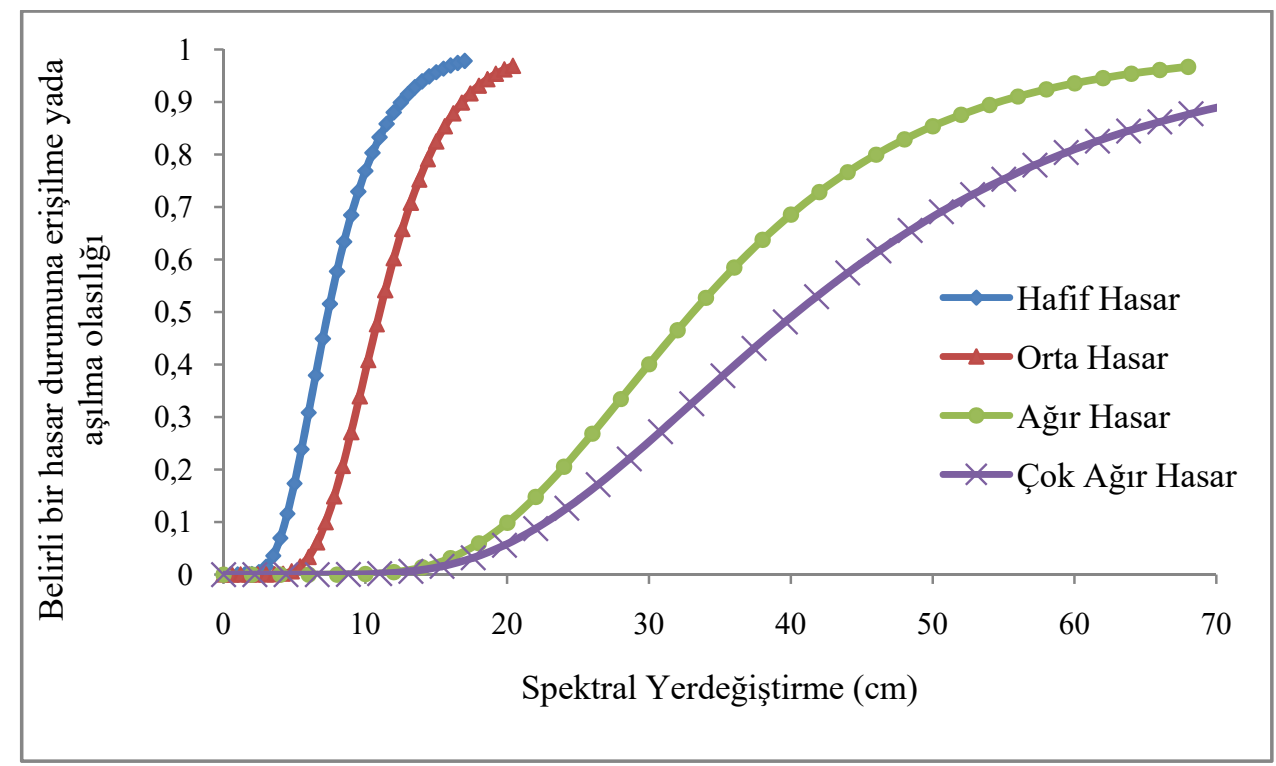

Şekil 15. Grup 98Ö67K kirllganlık eğrileri

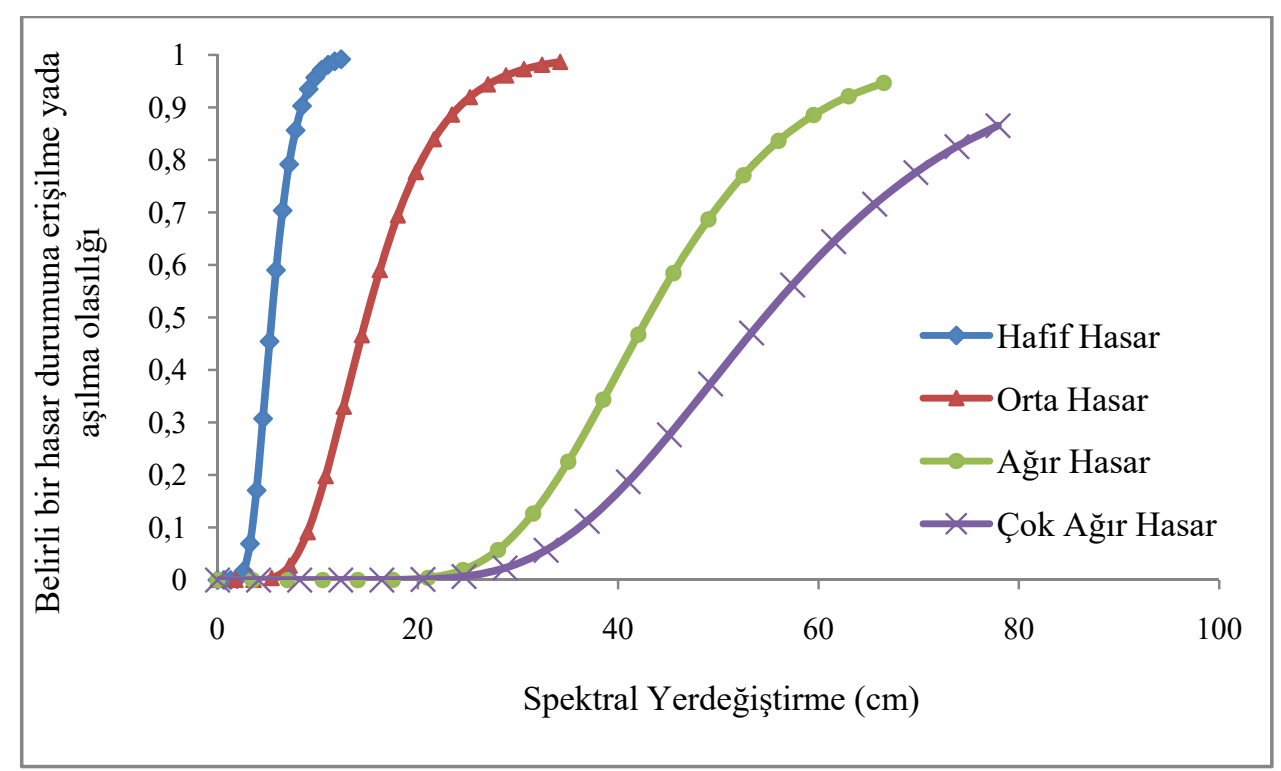

Şekil 16. Grup 98S67i kurllganlı eğrileri 


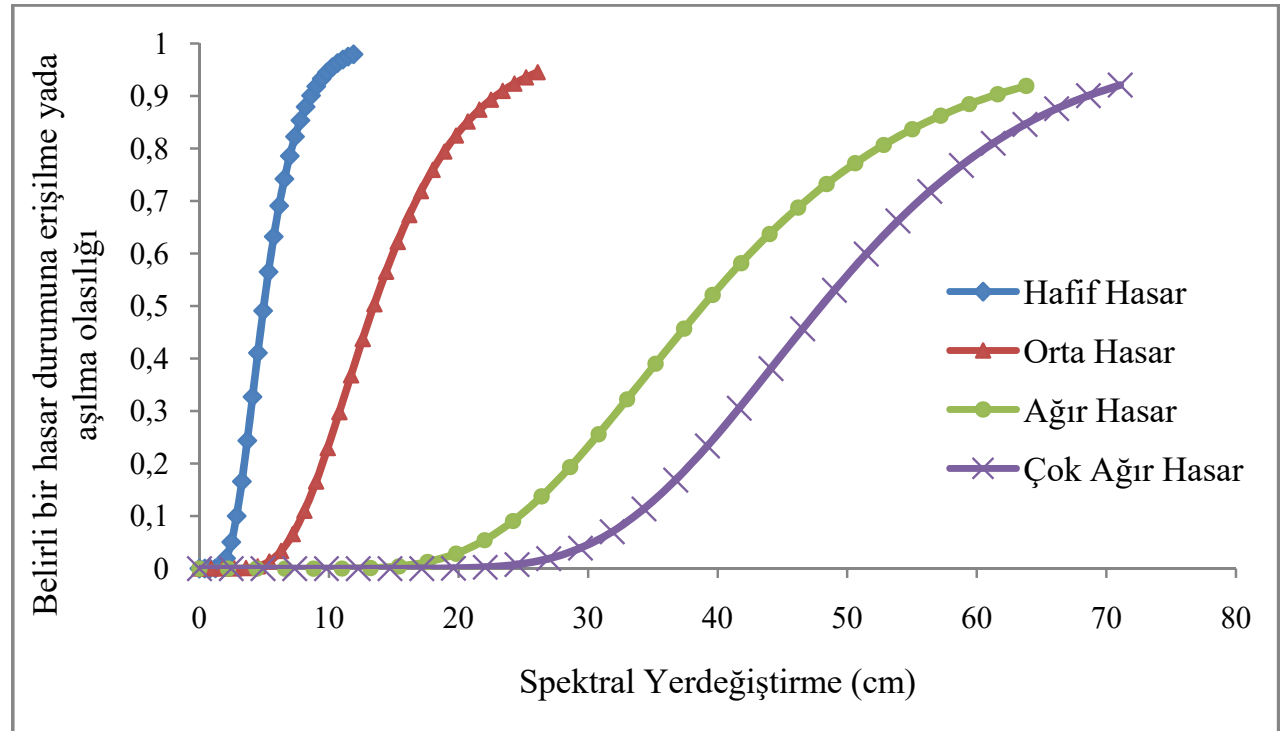

Şekil 17. Grup 98S67K kurllganlık eğrileri

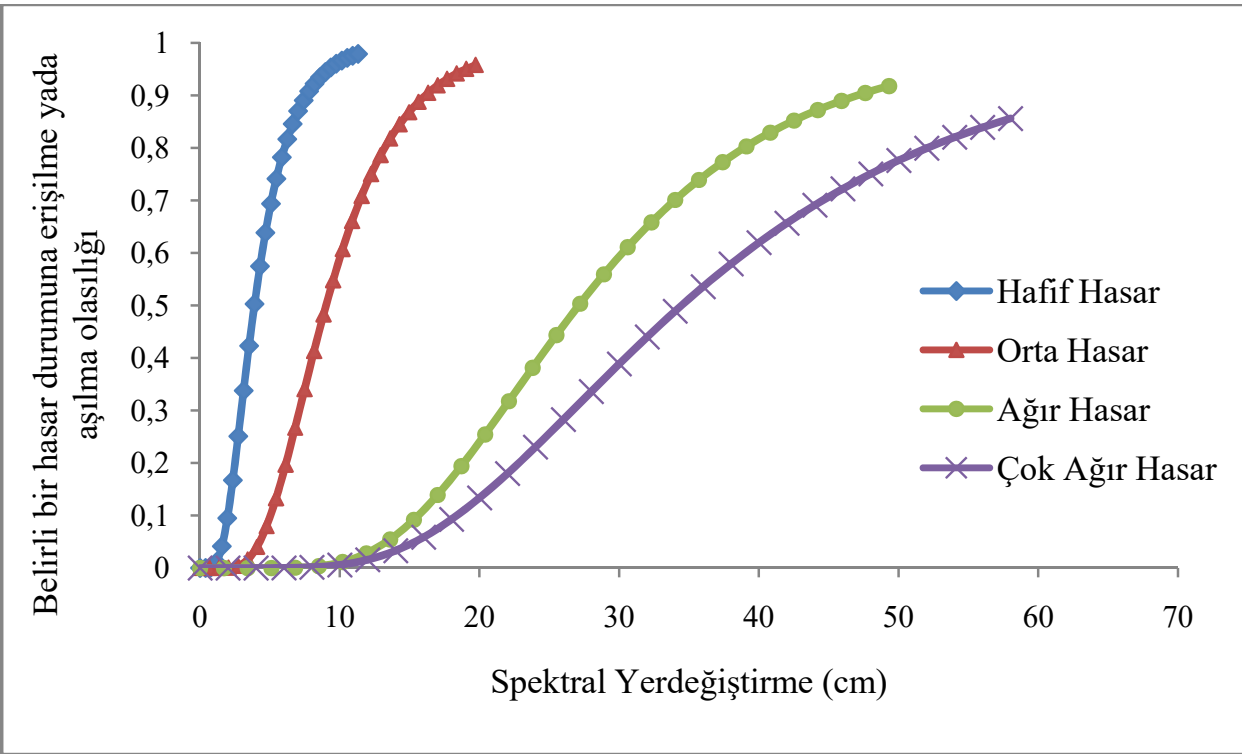

Şekil 18. Grup BPÇ kirılganlık eğrileri 


\section{SAYISAL BULGULAR}

Çalışmada incelenen yapılar için; zemin katın betonarme kesit alanının zemin katın oturum alanına bölünmesiyle elde edilen betonarme oranı $\% 0,5$ ile $\% 3$ arasında değişim göstermiş̧tir. Betonarme oranı kadar betonarme kalitesi de önem arz etmektedir. Yıllara göre kullanılan beton sınıfının arttığı açıkça görülmektedir.

Bir hızlı değerlendirme yöntemi olarak performans sıralamasına tabi tutulan yapılar, puanlarına göre değerlendirildiğinde; 1998 sonrası yapılan binaların performans puanlarının da 1998 öncesi yapılan binaların performans puanlarından daha yüksek olduğu görülmektedir. Binalar; iyi kalite ve kötü kalite olmak üzere 2 kalite sınıfında ele alınmıştır. Riskli Bina Tespit Esaslarına ilişkin yönetmelikte ayrıntılı olarak anlatılan performans puanlaması sistemine göre yapılan sıralama, binaların deprem riski açısından genel bir fikir vermektedir. Bu çalışmada genellikle en yüksek performans puanlı yapıların 1 ve 2 katlı yapılar olduğu, en düşük performans puanlı yapıların ise 6 ve 7 katlı yapılar olduğu göze çarpmaktadır. Bu sonuçlar; kat adedi arttıkça binaların depremde daha fazla hasar görme olasılığının da arttığını açıkça ortaya koymaktadır. İncelenen binaların performans puanlarını düşüren en önemli olumsuzlukların ise yumuşak kat, zayıf kat ve ağır çıkmalar olduğu görülmektedir. Araştırmaya konu olan binalarda en fazla rastlanan olumsuzluk olarak ağır çıkmalar ön plana çıkmaktadır. Özellikle 3 ve üzeri kat adedine sahip binaların yaklaşık \%30'unda en az bir yönde ağır çıkma bulunmaktadır.

Performans sıralaması yöntemi, binaların deprem performansları ve risk durumları hakkında genel bir fikir vermekle birlikte, bu çalışmada, puanlar sadece binaların sınıflandırılması amacıyla kullanılmıştır. Depremde ortaya çıkabilecek sonuçları daha gerçekçi biçimde tahmin edebilmek içinse her bir binaya doğrusal olmayan statik itme analizi uygulanmış ve binaların kapasite diyagramları elde edilmiştir.

İtme analizi sonuçları değerlendirildiğinde, çoğunlukla performans sıralamalarıyla örtüşen sonuçlar elde edilmiştir. Nonlinear statik itme analizi sonuçlarına göre çalışmadaki farklı grup binaları birbirleriyle karşılaştırabilmek için, periyot, süneklik, taban kesme kuvveti katsayısı parametrelerin grup ortalamaları Tablo 3'te listelenmiştir.

Tabloda her bir bina grubu için hesaplanan o gruptaki binaların ortalama periyot, ortalama süneklik ve ortalama taban kesme kuvveti katsayıları görülmektedir. Binaların yatay yer değiştirme cinsinden süneklik kapasiteleri denklem 4'e göre hesaplanmıştır.

Denklem 4'te $\mu$, yatay yerdeğiştirme cinsinden süneklik kapasitesini tanımlamaktadır. $\delta \mathrm{u}$; bina tepe noktasının en büyük yatay yerdeğiştirme değerini ve $\delta y$; doğrusal hareketin bittiği andaki tepe noktası yerdeğiştirme değeridir.

$\mu=\delta \mathrm{u} / \delta \mathrm{y}$

Dayanım açısından kıyaslama yapabilmek amacıyla Tablo 3'teki bir diğer parametre de en yüksek taban kesme kuvvetinin $\left(\mathrm{V}_{\mathrm{y}}\right)$ toplam bina ağırlığına $(\mathrm{W})$ oranı şeklinde belirlenen taban kesme kuvveti katsayısıdır.

Plandaki boyutlarında ve her iki doğrultuda yatay yükler etkisinde etkin çalışan kolon sayılarında önemli farklar bulunmayan binaların, her iki doğrultuda da deprem yükleri altında davranışlarının (dayanım ve yerdeğiştirme kapasitelerinin) birbirine yakın olduğu 
söylenebilir. Binaların taşıyıcı sistemini oluşturan çerçevelerin, özellikle binanın plandaki her iki doğrultusu boyunca sürekli olması, binanın yatay yük dayanım ve yerdeğiştirme kapasitesini artırmaktadır.

Tablo 3. Bina Gruplarının Ortalama Periyot, Süneklik ve Taban Kesme Kuvvet Katsayıları

\begin{tabular}{|c|c|c|c|}
\hline Bina Tipi & $\begin{array}{c}\text { Periyot } \\
(\mathrm{t})\end{array}$ & Süneklik $(\mu)$ & $\begin{array}{c}\text { Taban Kesme } \\
\text { Kuvveti Katsayisı } \\
(\text { Vy/W })\end{array}$ \\
\hline $98 \mathrm{O} 12$ & 0,351 & 4,12 & 0,1524 \\
\hline $98 \mathrm{~S} 12$ & 0,318 & 5,90 & 0,2286 \\
\hline $98 \mathrm{O} 35 \dot{\mathrm{I}}$ & 0,467 & 4,54 & 0,1978 \\
\hline $98 \mathrm{O} 35 \mathrm{~K}$ & 0,533 & 4,23 & 0,1664 \\
\hline $98 \mathrm{~S} 35 \dot{\mathrm{I}}$ & 0,410 & 6,71 & 0,2483 \\
\hline $98 \mathrm{~S} 35 \mathrm{~K}$ & 0,476 & 6,32 & 0,2219 \\
\hline $98 \mathrm{O} 6 \mathrm{I}$ & 0,781 & 4,27 & 0,1692 \\
\hline $98 \mathrm{O} 67 \mathrm{~K}$ & 0,893 & 3,95 & 0,1437 \\
\hline $98 \mathrm{~S} 67 \dot{\mathrm{I}}$ & 0,695 & 6,61 & 0,2376 \\
\hline $98 \mathrm{~S} 67 \mathrm{~K}$ & 0,782 & 6,32 & 0,2193 \\
\hline BPÇ & 0,584 & 5,33 & 0,2314 \\
\hline
\end{tabular}

Bu çalışmada kullanılan kırılganlık eğriler basitleştirilmiş bir ifadeyle; hasar sınırları belli olan bir grup binanın spektral deplasmana göre hasar dağılımını gösteren grafiklerdir. Kırılganlık eğrileri ve pushover analizi sonuçları birlikte ele alındığında; betonarme perde ve çerçeve sistemlerin birlikte kullanılığı binalar (Grup BPÇ) belirgin biçimde diğer gruplardan farklı davranış göstermektedir. Binada perde duvar bulunan sistemlerin yatay yük kapasitesinin, diğer grup binalara göre belirgin şekilde arttı̆̆ gözlenmektedir. Benzer şekilde; taşıyıcı sisteminde betonarme çerçevenin yanı sıra perde duvarların da kullanıldığı yapıların yanal ötelenmeleri de belirgin biçimde azalmaktadır. Bu çalışmada ele alınan bina grupları incelendiğinde betonarme perde+çerçeve sistemli binaların aynı kat adedine sahip çerçeve sistemli binalara oranla yaklaşı $\% 50$ oranında daha az yanal ötelenme yaptığı gözlenmiştir. Çalışmadaki bütün grupların kırılganlık eğrilerini birlikte değerlendirebilmek için 11 grup binanın aynı hasar seviyesine ait eğrileri Şekil 19- Şekil 22'de aynı grafik üzerinde karşılaş̧ırılmışır. Hafif hasar olasılık seviyesine ait kırılganlık eğrileri; Şekil 19'da, orta hasar olasılık seviyesine ait kırılganlık eğrileri Şekil 20'de, Ağır hasar seviyesi için oluşturulan kırılganlık eğriler Şekil 21 'de ve çok ağır hasar hasar olasılık seviyesi için oluşturulan kırılganlık eğriler Şekil 22'de verilmiştir.

Taşıyıcı sistemi betonarme çerçeve olan binalar kendi içinde karşılaştırıldığında; 1998 öncesi inşa edilen yapılarda hasar olasılık yüzdelerinin aynı kat adedine sahip 1998 ve 
sonrası inşa edilen binalara göre daha yüksek olduğu fark edilmektedir. $\mathrm{Bu}$ fark genel olarak bütün hasar seviyelerinde eğrilerin eğimi boyunca belirgindir.

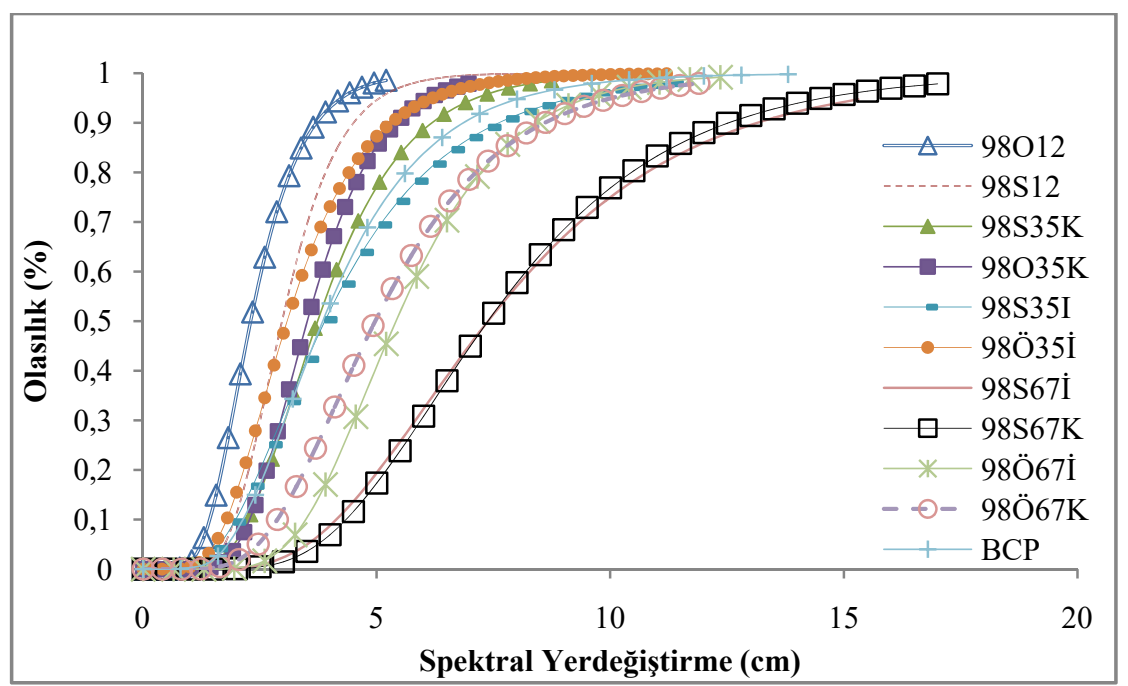

Şekil 19. Hafif hasar seviyesi kırılganlık ĕgrileri

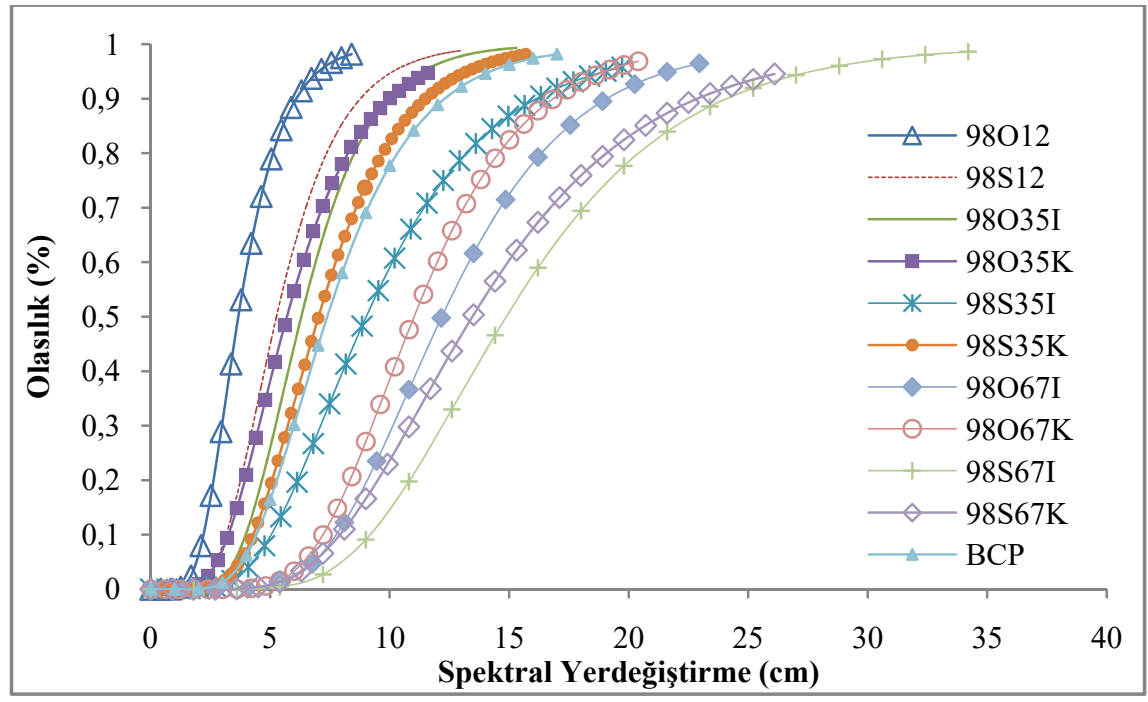

Şekil 20. Orta hasar seviyesi kırılganlık ĕgrileri 


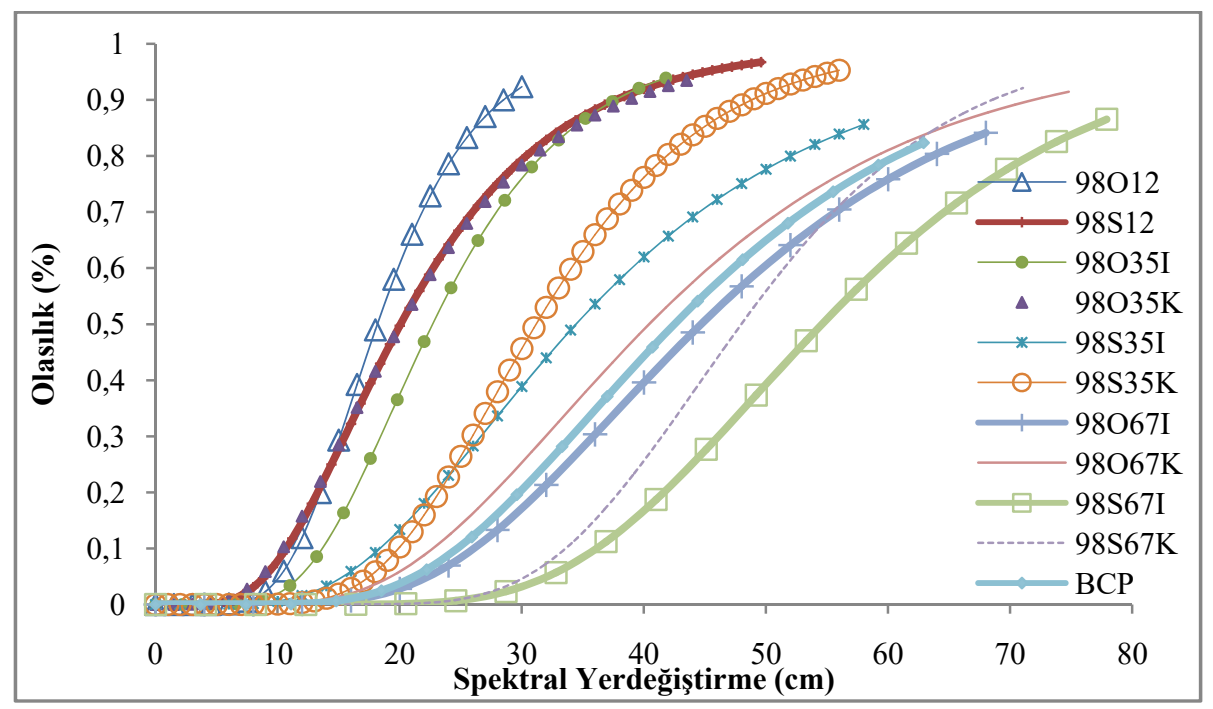

Şekil 22. Çok ă̆ır hasar seviyesi kırılganlık ĕgrileri

\subsection{Sonuçların Benzer Çalışmalarla Karşılaştırılması}

$\mathrm{Bu}$ çalışmalarda ülkemizdeki farklı yapı tiplerini temsil eden birçok kırılganlık eğrisi geliştirilmiştir. $\mathrm{Bu}$ çalışmada elde edilen eğriler; gerek yapı tipleri, gerekse hasar parametresi olarak benzer özellikteki yapı stokunu içeren eğriler ile karşılaştırılması faydalı olacaktır. Ülkemizde betonarme yapıların hasar olasılıkları üzerine yapılan çalışmalardan iki tanesi İzmir ve İstanbul illerimiz için geliştirilen Deprem Master Planlarıdır. İzmir için 1975 sonrası inşa edilmiş 1-2 katlı betonarme binalar için elde edilen kırılganlık eğrileri Şekil 22'deki gibidir.

Değerlendirme için \%50 hasar olasılığını gösteren tam orta nokta referans olarak kabul edilirse; Şekil 22'ye göre; İzmir için 1-2 katlı yapıların hafif hasar olasılığı 0-2cm, orta hasar olasılığı $2-3 \mathrm{~cm}$, ağır hasar olasılığ $3-8 \mathrm{~cm}$ ve çok ağır hasar olasılığı $8-20 \mathrm{~cm}$ aralığında dağılım göstermektedir. Bu değerler, bu çalışmada 1998 öncesi inşa edilmiş 1-2 katlı yapılar için elde edilen dağılımla yaklaşık olarak örtüşmektedir. İzmir Deprem Master Planı'nın 2000 yılında hazırlandığı göz önüne alındığında envanterdeki yapıların büyük çoğunluğunu 1998 öncesi yapıların bu benzerliğin sebebi olarak ön plana çıkmaktadır.

Şekil 23'te ise İzmir'deki 1975 sonrası 3-5 katlı yapılar için elde edilmiş kırılganlık eğriler görülmektedir.

Değerlendirme için yine eğrilerin orta noktası referans olarak kabul edilirse; Şekil 22'ye göre; hafif hasarın olasılığı yaklaşık olarak $0-3 \mathrm{~cm}$, orta hasar olasılığ $3-5 \mathrm{~cm}$, ağır hasar olasılığı $5-13 \mathrm{~cm}$ ve çok ağır hasar olasılığı $13-30 \mathrm{~cm}$ arasında dağılım göstermektedir. İzmir'deki 3-5 katlı yapılar için bulunan değerler yine bu çalışmada 1998 öncesi inşa edilmiş 3-5 katlı yapılar için elde edilen dağılımla yaklaşık olarak örtüşmektedir. 
Farklı Tip Betonarme Binalar İçin Geliştirilmiş Hasar Tahmin Yöntemleri

Şekil 24'te ise İzmir'deki 1975 sonrası 6 ve daha fazla katlı yapılar için elde edilmiş kırılganlık eğriler görülmektedir.

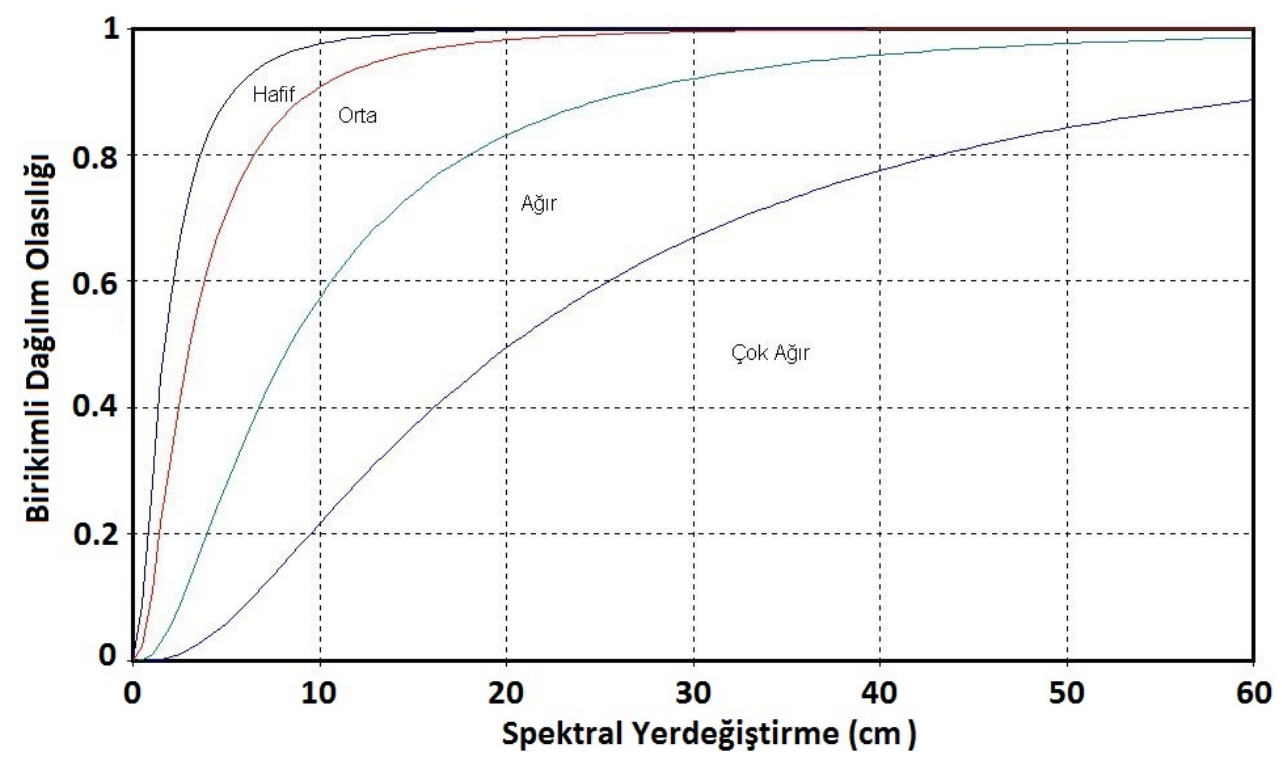

Şekil 22. İzmir'de 1975 sonrası inşa edilmiş 1-2 katlı betonarme binalar için kurılganlık eğrileri [26]

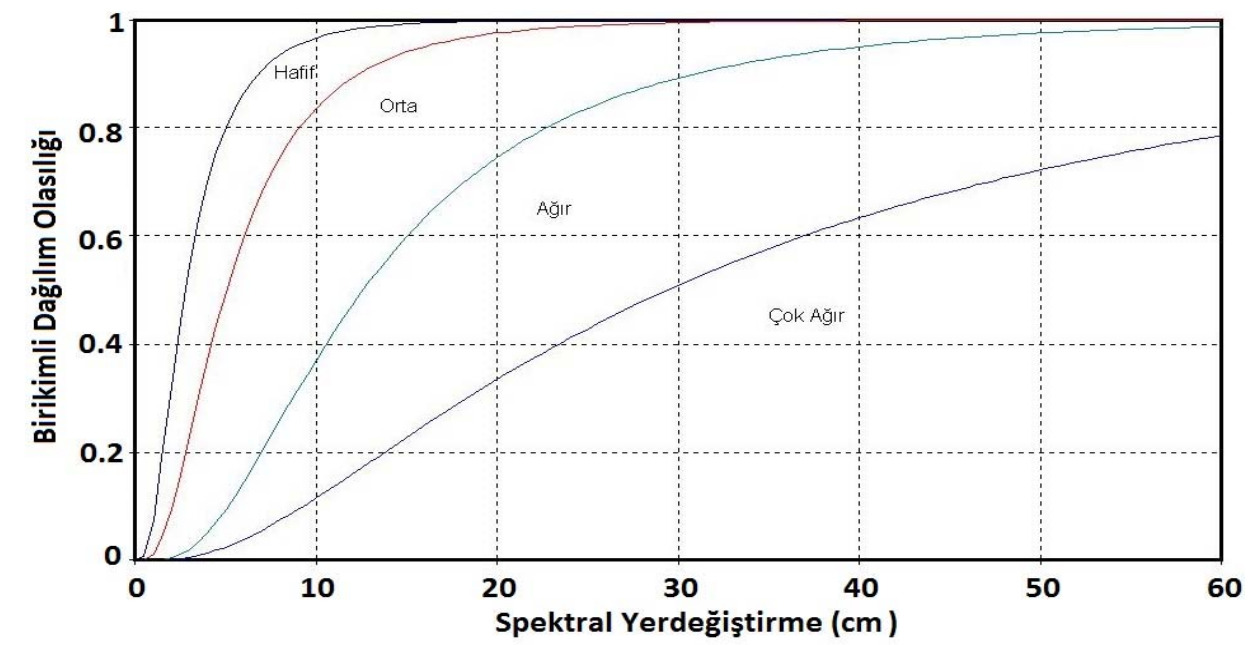

Şekil 23. İzmir'de 1975 sonrası inşa edilmiş 3-5 katlı betonarme binalar için kırılganlık eğrileri [26] 


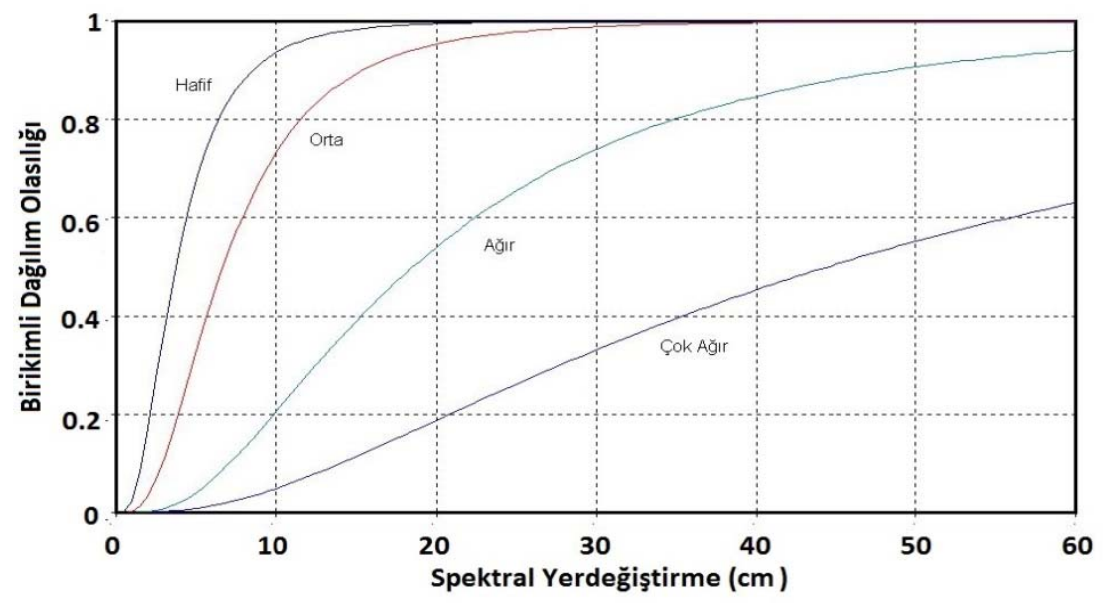

Şekil 24. İzmir'de 1975 sonrası inşa edilmiş 6 ve daha fazla katlı betonarme binalar için kirllganlik eğrileri [26]

Şekil 24.'teki hasar dağılımında; ağır hasar ve çok ağır hasar seviyesi eğrilerinin bu çalışmada 1998 öncesi 6-7 katlı binaların hasar dağılımdan daha büyük yerdeğiştirme değerleri gösterdiği dikkat çekmektedir. Bu durumun envanterdeki binaların kat sayısı farklarından kaynaklandığı düşünülmektedir. Bu çalışmada kullanılan binalarda en yüksek kat adedi 7 kat olmasına karşın, İzmir için yapılan çalışma envanterinde çok sayıda 8 ve üzeri kat adedine sahip bina bulunmaktadır. İstanbul Deprem Master Planı kapsamında yapılan çalışmalarda da benzer yapı tipleri için benzer yanal yerdeğiştirme sonuçları elde edilmiştir [27].

Bu çalışmalara paralel olarak Şekil $25^{\prime}$ te HAZUS çalışmasında orta katlı betonarme yapılar için önerilen kırılganlık eğrileri görülmektedir.

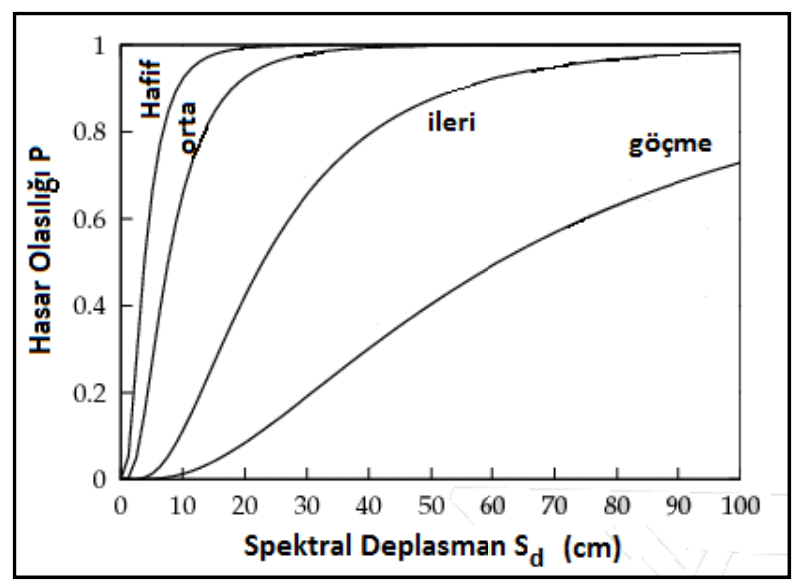

Şekil 25. Orta Katlı Betonarme Yapılar İçin Kırllganlık eğrileri [28] 
Ülkemizde meydana gelen büyük depremlerin hasar tespit raporları incelendiğinde; 1999 Marmara depreminde, incelenen 200.000'in üzerinde betonarme konutun yaklaşı \% $\% 30$ 'u ağır hasarlı veya yıkık olarak rapor edilmiştir [27, 29, 30, 31]. Yine 2011 Van depreminde incelenen 12500 binadan yaklaşık \%25'inin ağır hasarlı olduğu rapor edilmişstir [32].

Sözkonusu depremlerde tespit edilen hasarlı binaları bu çalışmadaki bina guruplarıyla bire bir eşleştirmek mümkün olmamakla birlikte, Marmara depreminde genel olarak 1998 öncesi inşa edilmiş orta katlı betonarme binaların yoğunlukta olduğu tahmin edilmektedir $[34,35,36,37]$. Van depremindeki hasarlı binalarda ise 1998 öncesi ve sonrası inşa edilmiş yapıların karışık olduğu gözlenmiş̧tir [32, 38, 39]. Mevcut deprem hasar raporları ile bu çalışmada önerilen yöntem sonuçlarını en yakın biçimde kıyaslayabilmek amacıyla Tablo 4 ve Tablo 5'te 6 Katlı betonarme binalar referans alınmıştır. Tablo 4 'te Marmara ve Van depremlerinde 6 katlı betonarme binaların aldığı hasarlar görülmektedir. Tablo 5 ise, bu çalışmada önerilen yöntemle 6 ve 7 katlı betonarme binalarda oluşabilecek hasar tahminlerini göstermektedir.

Tablo 4. 6 Katl Betonarme Binalar İçin 1999 Marmara ve 2011 Van Depremlerinde Tespit Edilen Hasar Durumlarl [32, 34, 35, 36, 37, 38, 39]

\begin{tabular}{|l|l|l|l|l|}
\hline \multicolumn{1}{|c|}{ Bina Grubu } & Hasarsız & $\begin{array}{c}\text { Hafif } \\
\text { Hasarlı }\end{array}$ & $\begin{array}{c}\text { Orta } \\
\text { Hasarlı }\end{array}$ & $\begin{array}{c}\text { Ağır } \\
\text { Hasarlı } \\
\text { veya Ykık }\end{array}$ \\
\hline 2011 Van Depremi & $\% 20$ & $\% 26$ & $\% 20$ & $\% 34$ \\
\hline 1999 Marmara Depremi & $\% 9$ & $\% 23$ & $\% 51$ & $\% 17$ \\
\hline
\end{tabular}

Tablo 5. 6 Katlı Binaları İçeren Grupların Hasar Olasıllkları

\begin{tabular}{|c|c|c|c|c|}
\hline Bina Grubu & $\begin{array}{c}\text { Hasarsızl } \\
1 \mathrm{k} \\
\text { Olasıllığ }\end{array}$ & $\begin{array}{c}\text { Hafif } \\
\text { Hasar } \\
\text { Olasillğg }\end{array}$ & $\begin{array}{c}\text { Orta } \\
\text { Hasar } \\
\text { Olasilığ } 1\end{array}$ & $\begin{array}{c}\text { Ağır Hasar } \\
\text { veya } \\
\text { Göçme } \\
\text { Olasılığ1 }\end{array}$ \\
\hline 980̈67İ & $\% 24$ & $\% 30$ & $\% 27$ & $\% 21$ \\
\hline 98Ö67K & $\% 20$ & $\% 15$ & $\% 42$ & $\% 28$ \\
\hline 98S67İ & $\% 24$ & $\% 41$ & $\% 28$ & $\% 17$ \\
\hline $98 \mathrm{~S} 67 \mathrm{~K}$ & $\% 20$ & $\% 38$ & $\% 22$ & $\% 20$ \\
\hline
\end{tabular}

Tablo 4 ve Tablo 5 birlikte ele alındığında; 1999 Marmara depreminde 6 katlı binaların $\% 17$ 'si, Van depreminde ise \%34'ü ağır hasarlı ve yıkık olarak görülmektedir. Bu çalışmada önerilen yönteme göre ise Ağır hasarlı ve yıkık bina oranının \%17 ile \%28 arasında olacağı hesaplanmıştır.

Yapılan bir çok çalışma Türkiye genelinde yaygın olarak kullanılan az ve orta katlı betonarme yapıların yanal deplasman altında benzer hasar dağılımları gösterdiğini ortaya koymaktadır $[2,5,13,14]$. 


\subsection{Sonuç ve Öneriler}

Taşıyıcı sistemde betonarme çerçevelerle birlikte betonarme perde duvarlara yer verilmesinin yapı rijitliğini önemli ölçüde artırdığı görülmektedir. $\mathrm{Bu}$ çalışma perde+çerçeve sistemlerin ağır hasar riskini azaltmakta oldukça etkili olduğunu tekrar göstermiş̧tir. Buna rağmen çalışmada incelenen binalarda perde duvar kullanımının oldukça seyrek düzeyde kaldığı gözlemlenmiştir. Taşıyıcı sisteminde betonarme çerçeve ve perde duvarların birlikte kullanıldığı bu tür binaların birçoğunda ise perde duvar sayısı sınırlı düzeyde kalmıştır. Çalışmada incelenen perde+çerçeve sistemli binalarda, betonarme kesit alanları dikkate alındığında; perde duvarların kolonlara oranı \%10-30 arasında değişmektedir. Taşıyıcı sistemde kullanılan perde duvar sayısının artırılması binada kullanılan betonarme oranını artırmaktadır. Depreme karşı daha dayanıklı yapılar inşa etmek için; bundan sonra inşa edilecek olan betonarme yapılarda perde duvar oranlarının artııılması oldukça önemlidir. Çalışmadaki binaların betonarme alanının zemin kat alanına oranı binde 5 ile yüzde 3 arasında değişiklik göstermiştir. Yönetmelikler düzenlenirken binaların kat alanına bağlı olarak minimum betonarme alanı ile ilgili düzenlemelerin de yapılması faydalı olacaktır. Her geçen gün beton teknolojisindeki gelişmeler ile birlikte beton kalitesinin artması daha az beton alanı ile yönetmeliklerin gerektirdiği şartları sağlayabilmeyi mümkün kılmaktadır. Fakat binadaki taşıyıcı eleman kesitlerinin küçülmesi, depremde dezavantaj teşkil edebilmektedir. $\mathrm{Bu}$ soruna bir çözüm önerisi olarak; yönetmeliklerin betonarme binalar için sadece çerçeve sistemlerle çözüm yapılması yerine perde duvar kullanılmasını teşvik edecek şekilde düzenlenmesi faydalı olacaktır.

\section{Kaynaklar}

[1] TUBITAK Türkiye Ulusal Deprem Araştırmaları Programı 2005-2014, Tübitak Yayınları, Ankara, 2005.

[2] Uçar, T., Düzgün, M. Betonarme binalar için artımsal itme analizi esaslı analitik hasargörebilirlik eğrilerinin oluşturulması. İMO Teknik Dergi. 2013, (402), 64216446.

[3] Erdik, M., Doyuran, V., Gülkan, P., Akka , N., (1983). Second Turkish Nuclear Power Plant Site Selection Investigations: A Probabilistic Assessment of the Seismic Hazard in Turkey, Earthquake Engineering Research Center, Middle East Technical University, METU/EERC Report No. 83-01, Ankara.

[4] Akkaya, A.D. and Yücemen, M.S., "Stochastic Modeling of Earthquake Occurrences and Estimation of Seismic Hazard: A Random Field Approach", Probabilistic Engineering Mechanics, 2002, (17), 1-13.

[5] Özcebe, G., Yücemen, M.S. and Aydoğan, V., "Statistical Seismic Vulnerability Assessment of Existing Reinforced Concrete Buildings on a Regional Scale", Journal of Earthquake Engineering, 2004, 8(5), 1-25.

[6] Kemec S, Duzgun HSB (2006a) Use of 3D visualisation in natural disaster risk assessment for urban areas. In: Abdulrahman A, Zlatanova S, Coors V (eds) Lecture notes in geoinformation and cartography series, innovations in 3D geo information systems. Springer, New York, pp 557-566 
Farklı Tip Betonarme Binalar İçin Geliştirilmiş Hasar Tahmin Yöntemleri

[7] Kemec S, Duzgun HSB (2006b) 3-D visualisation of urban earthquake risk, ECI conference: geohazards - technical, economical and social risk evaluation 18-21 June 2006, Lillehammer, Norway

[8] Binici, B., Yakut, A., Ozcebe, G., Erenler, A., "Provisions For The Seismic Risk Evaluation Of Existing Reinforced Concrete Buildings In Turkey Under The Urban Renewal Law” Earthquake Spectra, 2015, 31(3), 1353-1370.

[9] Yücemen, M. S., "Probabilistic Assessment of Earthquake Insurance Rates for Turkey “, Natural Hazards, 2005, (35) 291-313.

[10] Yakut, A., Özcebe, G. and Yücemen, M.S., "Seismic Vulnerability Assessment Using Regional Empirical Data", Earthquake Engineering and Structural Dynamics, 2006, (35),1187-1202.

[11] Askan, A. and Yücemen, M. S., Probabilistic Methods for the Estimation of Potential Seismic Damage: Application to Reinforced Concrete Buildings in Turkey. "Structural Safety", 32, (2010), p.262-271.

[12] Duzgun, H. S. B., Yucemen, M. S., Kalaycioglu, H. S., Celik, K., Kemec, S., An Integrated Earthquake Vulnerability Assessment Framework for Urban Areas. "Natural Hazards", 59, (2011), p.917-947.

[13] Un, E., Erberik, M. A., Askan, A. Performance assessment of Turkish residential buildings for seismic damage and loss estimation. Journal of Performance of Constructed Facilities. 2015, doi: 10.1061/(ASCE)CF.1943-5509.0000547.

[14] Güneyisi, E. M., Şahin, N. D. Viskoelastik sönümleyicili yapilarin hasar potansiyeli eğrilerinin belirlenmesi, 1. Türkiye Deprem Mühendisliği ve Sismoloji Konferans1, 11-14 Ekim, Ankara, 2011.

[15] Kayabalı, K., (2002). Modeling of Seismic Hazard for Turkey Using the Recent Neotectonic Data, Engineering Geology, Vol. 63, 221-232.

[16] Deniz A (2006) Estimation of earthquake insurance premium rates for Turkey. M.Sc. Thesis, Department of Civil Engineering, METU, Ankara

[17] Abo-El-Ezz, A., Nollet, M. J., Nastev, M. Seismic fragility assessment of low-rise stone masonry buildings. Earthquake Engineering and Engineering Vibration. 2013, 12(1), 87-97.

[18] Hsieh, M. H., Lee, B. J., Lei, T. C., Lin, J. Y. Development of medium and low rise reinforced concrete building fragility curves based on Chi-Chi Earthquake data. Natural Hazards. 2013. 69(1), 695-728.

[19] Lignos, D. G., Karamanci, E. Drift-based and dual-parameter fragility curves for concentrically braced frames in seismic regions. Journal of Constructional Steel Research. 2013, 90(1), 209-220.

[20] Casotto, C., Silva, V., Crowley, H., Nascimbene, R., Pinho, R. Seismic fragility of Italian RC precast industrial structures. Engineering Structures. 2015, (94), 122-136.

[21] Kırçıl, M. S., Polat, Z. Fragility analysis of mid-rise R/C frame buildings. Engineering Structures. 2006, 28(9), 1335-1345. 
[22] Afet Riski Altındaki Alanların Dönüştürülmesi Hakkında Kanunun Uygulama Yönetmeliğinde Değişiklik Yapılmasına Dair Yönetmelik, T.C Çevre Ve Şehircilik Bakanlı̆̆ı, 2013.

[23] Mander, J. B., Priestley, M. J. N., and Park, R. (1988). "Theoretical Stress-Strain Model for Confined Concrete.” J. Struct. Engrg., ASCE, 114(8), 1804-1826.

[24] Deprem Bölgelerinde Yapılacak Binalar Hakkında Yönetmelik, Bayındırlık ve İskan Bakanlığı, Resmi Gazete No: 26454, Ankara, 2007.

[25] Quick Guide to HAZUS-MH MR1, Federal Emergency Management Agency, ESRI, California, June 2006.

[26] İzmir Deprem Senaryosu ve Deprem Master Planı, İzmir Büyükşehir Belediyesi ve Boğaziçi Üniversitesi, İzmir, 2000.

[27] Ansal, A. İstanbul deprem senaryoları. İstanbul Teknik Üniversitesi Vakfı Yayını, Deprem Dosyası. 2003, 66(1), 16-26.

[28] Molina, S., User manual for the earthquake loss estimation tool: SELENA, Norsar and Universidad de Alicante, Norsar, October 1, 2010.

[29] İnan, E., Çolakoğlu, Z., Koç, N., Bayülke, N., Çoruh, E., (1996). Catalogue of Earthquakes Between 1976-1996 with Acceleration Records, Earthquake Research Department of the General Directorate of Disaster Affairs Publications, Ministry of Public Works and Settlement, Ankara, (in Turkish).

[30] Bal, I. E., Crowley, H., Pinho, R., "Displacement-Based Earthquake Loss Assessment for an Earthquake Scenario in Istanbul”, Journal of Earthquake Engineering, 2008, 12(S2), 12-22.

[31] Özmen, B., (1999). Iso-intensity map of İzmit earthquake, Earthquake Research Department, General Directorate of Disaster Affairs, Ankara, available on-line in Turkish at http://www.deprem.gov.tr/raporlar.htm.

[32] Görgün, E., (2003). Calibration of Various Magnitude Scales in Turkey Using Broadband Data, M.Sc. Thesis, Kandilli Observatory and Earthquake Research Institute, Bogaziçi University, İstanbul.

[33] Afet Raporu: "Müdahale,İileştirme ve Sosyoekonomik Açıdan Van Depremi", T.C. Başbakanlık Afet ve Acil Durum Yönetimi Başkanlı̆̆ı̆, 2014, Ankara.

[34] Erdik M., Demircioglu M., Sesetyan K., Durukal E., Siyahi B.,"Earthquake hazard in Marmara region, Turkey, Soil Dynamic Earthquake Engineering, 2004, (24), 605-631

[35] Sümer, E., Türker, M., (2004). Building Damage Detection from Post-Earthquake Aerial Images Using Watershed Segmentation in Gölcük, Turkey, Proceedings, 20th International Society for Photogrammety and Remote Sensing Congress: GeoImagery Bridging. Continents, Commission 7, 642-647, İstanbul.

[36] Özmen, B., "17 Ağustos 1999 İzmit Körfezi Depreminin Hasar Durumu (Rakamsal Verilerle)", TDV/DR 010-53, Türkiye Deprem Vakfi, 2000. 
Farklı Tip Betonarme Binalar İçin Geliştirilmiş Hasar Tahmin Yöntemleri

[37] Sünbül, A. B., Dağdeviren, U., Gündüz, Z., Arman, H., “1999 Marmara Depremi Sonrası Adapazarı Şehir Merkezi Hasar Durumlarının Analizi Ve Depremin Ekonomik Boyutu", TMMOB Afet Sempozyumu, 5-7 Aralık 2007, Ankara.

[38] "Van Depremi Hasar Tespit Raporu” TMMOB Mimarlar Odası, 20 Ocak 2012, Ankara.

[39] Middle East Technıcal Unıversity Earthquake Engıneerıng Research Center "23 Ekim 2011 Mw 7.2 Van Depremi Sismik Ve Yapısal Hasara İlişkin Saha Gözlemleri" Rapor No: METU/EERC 2011-04, Kasım 2011, Ankara.

[40] Gürbüz, A. (2015) Manisa'daki perdeli ve perdesiz betonarme konut yapılarının deprem performansının belirlenmesi ve hasar olasılık eğrilerinin çizilmesi, Doktora Tezi, Manisa Celal Bayar Üniversitesi, Manisa. 